\title{
Molecular Proteomics and Signalling of Human Platelets in Health and Disease
}

\author{
Jingnan Huang ${ }^{1,2,3, *(\mathbb{D}}$, Pengyu Zhang ${ }^{1,2,4}$, Fiorella A. Solari ${ }^{1}{ }^{(0)}$, Albert Sickmann ${ }^{1,5,6}$, Angel Garcia ${ }^{3} \mathbb{C}^{\circ}$, \\ Kerstin Jurk ${ }^{4}(\mathbb{D})$ and Johan W. M. Heemskerk ${ }^{2, *,+} \mathbb{D}$
}

check for updates

Citation: Huang, J.; Zhang, P.; Solari, F.A.; Sickmann, A.; Garcia, A.; Jurk, K.; Heemskerk, J.W.M. Molecular Proteomics and Signalling of Human Platelets in Health and Disease. Int. J. Mol. Sci. 2021, 22, 9860. https:// doi.org/10.3390/ijms22189860

Academic Editor: Silvia S. Barbieri

Received: 20 July 2021

Accepted: 2 September 2021

Published: 13 September 2021

Publisher's Note: MDPI stays neutral with regard to jurisdictional claims in published maps and institutional affiliations.

Copyright: (c) 2021 by the authors. Licensee MDPI, Basel, Switzerland. This article is an open access article distributed under the terms and conditions of the Creative Commons Attribution (CC BY) license (https:// creativecommons.org/licenses/by/ $4.0 /)$.
1 Leibniz Institut für Analytische Wissenschaften-ISAS-e.V., 44139 Dortmund, Germany; pengyu.zhang@isas.de (P.Z.); fiorella.solari@isas.de (F.A.S.); sickmann@isas.de (A.S.)

2 Department of Biochemistry, CARIM, Maastricht University, 6229 ER Maastricht, The Netherlands

3 Center for Research in Molecular Medicine and Chronic Diseases (CIMUS), Universidade de Santiago de Compostela, 15706 Santiago de Compostela, Spain; angel.garcia@usc.es

4 Center for Thrombosis and Haemostasis, University Medical Center of the Johannes Gutenberg University Mainz, 55131 Mainz, Germany; kerstin.jurk@unimedizin-mainz.de

5 Medizinische Fakultät, Medizinische Proteom-Center, Ruhr-Universität Bochum, 44801 Bochum, Germany

6 Department of Chemistry, College of Physical Sciences, University of Aberdeen, Aberdeen AB24 3FX, UK

* Correspondence: j.huang@maastrichtuniversity.nl (J.H.); jwmheem722@outlook.com (J.W.M.H.); Tel.: +31-43-3881674 (J.H.); +31-43-3436835 (J.M.W.H.); Fax: +31-43-3884159 (J.W.M.H.)

† Present address, Synapse Research Institute Maastricht, Kon. Emmaplein 7, 6214 AC Maastricht, The Netherlands.

\begin{abstract}
Platelets are small anucleate blood cells that play vital roles in haemostasis and thrombosis, besides other physiological and pathophysiological processes. These roles are tightly regulated by a complex network of signalling pathways. Mass spectrometry-based proteomic techniques are contributing not only to the identification and quantification of new platelet proteins, but also reveal post-translational modifications of these molecules, such as acetylation, glycosylation and phosphorylation. Moreover, target proteomic analysis of platelets can provide molecular biomarkers for genetic aberrations with established or non-established links to platelet dysfunctions. In this report, we review 67 reports regarding platelet proteomic analysis and signalling on a molecular base. Collectively, these provide detailed insight into the: (i) technical developments and limitations of the assessment of platelet (sub)proteomes; (ii) molecular protein changes upon ageing of platelets; (iii) complexity of platelet signalling pathways and functions in response to collagen, rhodocytin, thrombin, thromboxane $\mathrm{A}_{2}$ and ADP; (iv) proteomic effects of endothelial-derived mediators such as prostacyclin and the anti-platelet drug aspirin; and (v) molecular protein changes in platelets from patients with congenital disorders or cardiovascular disease. However, sample sizes are still low and the roles of differentially expressed proteins are often unknown. Based on the practical and technical possibilities and limitations, we provide a perspective for further improvements of the platelet proteomic field.
\end{abstract}

Keywords: platelets; post-translational modification; proteins; signalling; receptors

\section{Introduction}

Platelets circulate as anucleated cells in the blood, where they are kept in a resting state by the vascular endothelium producing platelet inhibitors [1,2]. Alongside other functions, not addressed in this paper, platelets are of fundamental importance in primary and secondary haemostasis and arterial thrombosis [3]. An extensive network of molecular signal transduction processes in platelets allows their fast adhesion and secretion upon injury of the vessel wall or damage of an atherosclerotic plaque, and hence allows the formation of a rapidly growing thrombus $[4,5]$.

Because of their anucleate structure, gene transcription and ribosomal translation activities are restricted in platelets [6,7], resulting in a relatively stable proteome [8]. Given 
this, mass-spectrometry-based proteomic analyses can be a valuable tool to assess the molecular build-up especially of these out-differentiated cells.

\section{Overview of Platelet Proteomic Literature}

In the present paper, we provide a topical overview of how technical developments in the mass-spectrometric technologies are contributing to our knowledge of the basic proteome of freshly isolated and stored platelets, as well as of platelets stimulated via key receptor-dependent signalling mechanisms. Details of the 67 published platelet proteomic analyses are provided in Table S1 (search terms PubMed 2021: platelet proteomics, excluding non-human, not original protein lists and reviews). Extracted key characteristics per section are indicated in Table 1.

Table 1. Proceedings and characteristics per section of published proteomic studies regarding platelet purity, sample size, types of proteomes analysed and reported study limitations. For details per study, see Table S1. Abbreviation: PRM, parallel-reaction monitoring.

\begin{tabular}{|c|c|c|c|c|c|c|}
\hline Section & Year & $\begin{array}{l}\text { Purity } \\
\text { Checked }\end{array}$ & Sample Size & Type of (Sub)Proteomes & Reported Limitations & Pathway (GO) \\
\hline 3-Basic & $\geq 2011$ & $6 / 12$ & $20-250 \mu \mathrm{g}$ & $\begin{array}{l}\text { platelets, granules, } \\
\text { palmitoylation, } \\
\text { methylation }\end{array}$ & $\begin{array}{l}\text { unclear relation to } \\
\text { platelet functions, low } \\
\text { sample number }\end{array}$ & $8 / 12$ \\
\hline 4-Ageing & $\geq 2012$ & $3 / 12$ & $4-500 \mu \mathrm{g}$ & $\begin{array}{c}\text { stored platelets, } \\
\text { N-terminome, } \\
\text { extracellular vesicles }\end{array}$ & $\begin{array}{l}\text { unclear relation to } \\
\text { platelet functions, low } \\
\text { sample number }\end{array}$ & $7 / 12$ \\
\hline 5-GPVI & $\geq 2010$ & $8 / 11$ & $150-2500+\mu g$ & $\begin{array}{c}\text { platelets (label-free), } \\
\text { phosphorylation }\left(\mathrm{TiO}_{2}\right) \\
\text { acetylation, } \mathrm{PRM} \\
\text { targeted, ubiquitylation, } \\
\text { releasate }\end{array}$ & $\begin{array}{l}\text { limited protein recovery, } \\
\text { sample pooling }\end{array}$ & $7 / 11$ \\
\hline 6-CLEC-2 & $\geq 2012$ & $2 / 2$ & $150 \mu \mathrm{g}$ & $\begin{array}{c}\text { platelets, } \\
\text { phosphorylation }\end{array}$ & $\begin{array}{l}\text { limited protein recovery, } \\
\text { second mediator } \\
\text { interference }\end{array}$ & $2 / 2$ \\
\hline 7-PARs & $\geq 2015$ & $5 / 13$ & $24-150 \mu \mathrm{g}$ & $\begin{array}{c}\text { platelets (label-free), } \\
\text { phosphorylation }\left(\mathrm{TiO}_{2}\right), \\
\text { releasate, extracellular } \\
\text { vesicles }\end{array}$ & $\begin{array}{c}\text { sample pooling, low } \\
\text { sample number, } \\
\text { leukocyte contamination, } \\
\text { clinical relevance unclear }\end{array}$ & $12 / 13$ \\
\hline 8-ASA & $\geq 2017$ & $2 / 5$ & $5-100 \mu \mathrm{g}$ & $\begin{array}{c}\text { platelets, acetylation, } \\
\text { glycosylation }\end{array}$ & unclear clinical relevance & $3 / 5$ \\
\hline $\begin{array}{c}9- \\
\mathrm{ADP} / \mathrm{INH}\end{array}$ & $\geq 2014$ & $3 / 3$ & $100-800 \mu \mathrm{g}$ & $\begin{array}{c}\text { platelets, } \\
\text { phosphorylation }\left(\mathrm{TiO}_{2}\right)\end{array}$ & $\begin{array}{l}\text { low sample number, } \\
\text { unclear function of } \\
\text { phosphorylation }\end{array}$ & $2 / 3$ \\
\hline 10-PAT & $\geq 2010$ & $7 / 15$ & $40-600+\mu g$ & $\begin{array}{c}\text { platelets (label-free), } \\
\text { targeted, } \\
\text { phosphorylation, } \\
\text { N-terminome }\end{array}$ & $\begin{array}{l}\text { low patient number, } \\
\text { inter-patient variation, } \\
\text { unclear relation to } \\
\text { platelet functions }\end{array}$ & $8 / 15$ \\
\hline
\end{tabular}

With an estimated size of $\sim 10 \mathrm{k}$ unique proteins in nucleated cells $[9,10]$, proteome studies of human platelets have identified variable numbers of 2-6 k proteins (Figure 1A). From the 67 registered studies, including six papers with two categories (Table S1), many $(48 \%)$ used isolated, washed platelets of high purity (99-99.99\%). Given the small volume of platelets (9-11 fL) [2] and an abundant open canicular system, this purity cannot exclude contamination with proteins from plasma, red blood cells and leukocytes, which may affect study outcomes [11]. A minority of the studies investigated platelet releasates, ultracentrifuged platelet extracellular vesicles, or immuno-affinity fractions from platelets, with the latter providing lower numbers of proteins [12]. The early procedure of twodimensional gel separation of lysed platelets is still in use in some laboratories (12 papers), although this method is now mostly replaced by bottom-up LC-MS/MS analysis without gel separation. 
A

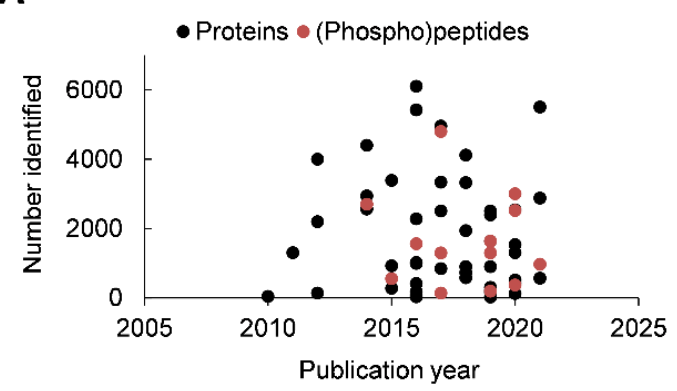

C

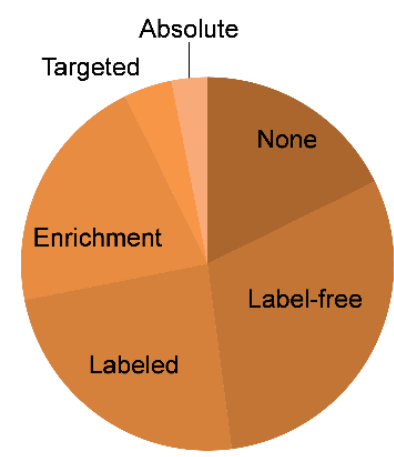

B
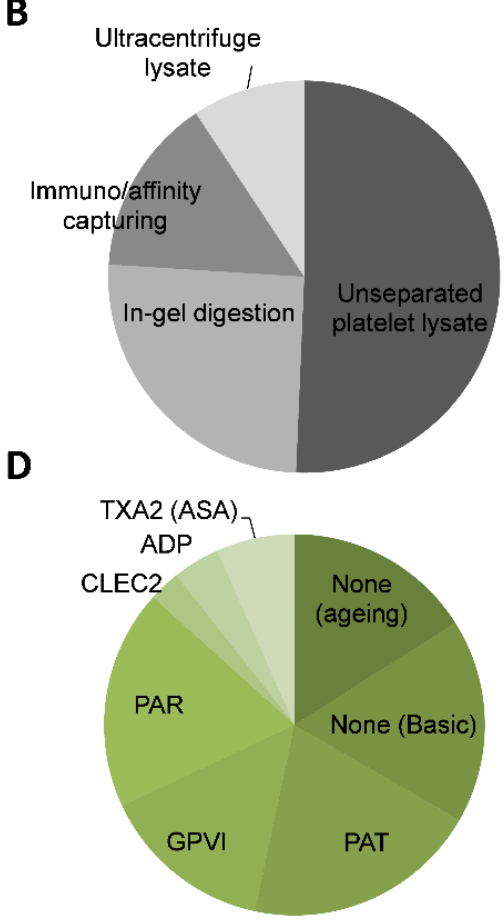

Figure 1. Overview of 67 platelet proteomic publications. (A), Numbers of identified proteins and (phospho)peptides in human platelets in publications over the years. (B), Distribution profile of proteomic papers for types of platelet preparations. Half of the collected papers (49\%) used trypsin treatment of unseparated platelet lysates; others used prior separation by gel electrophoresis and in-gel digestion (26\%), immuno/affinity capturing (15\%) or ultracentrifugation enrichment (9\%). (C), Distribution profile of proteomic quantification type. In 67 publications, $20 \%$ used no other method, $23 \%$ used stable isotope labelling, 30\% used label-free quantification, 22\% employed special peptides enrichments and 5\% employed targeted (4\%) or absolute quantification (1\%) methods. (D), Distribution profile of type of (stimulated) platelets used in 67 publications. Most papers used healthy donor platelets without agonist (33\%), patient platelets (PAT, 20\%) or platelets stimulated via GPVI (15\%) or PARs (17\%). Rarer was analysis of platelets stimulated via CLEC-2 (3\%), ADP (4\%) or TXA 2 /aspirin (7\%).

As the most common protein digestion method, about half of the collected papers $(49 \%)$ use trypsin treatment of total platelet lysates (Figure 1B). The usual sample workup is trichloroacetic acid and/or acetone precipitation and filter-aided sample preparation. Many of the 67 publications describe one or more additional sample treatment steps before uploading onto a column. These include stable isotope labelling (isobaric tags for relative and absolute quantification, iTRAQ or TMT 23\%), label-free quantification $(30 \%)$, enrichment (22\%, for phosphopeptides, N-terminal or glycopeptides) or targeted or absolute quantification (5\%) (Figure 1C). In recent years, label-free quantification has become possible with state-of-the-art mass spectrometers, but this method is demanding for subsequent data analysis [13,14]. As we detail below (Section 11), novel technical advances are gradually appearing in papers, such as label-free quantification methods, data-independent acquisition, targeted analysis with biomarker peptide references and well-plate-based sample workup.

The majority of the 67 publications state some study limitations. The most mentioned are: low peptide coverage linked to low protein abundance, complex spectral data analysis and missing (hydrophobic) peptide sequences [15]. It has been recognised that inter-lab differences in fractionation and instrumentation limit the comparison of the platelet (phospho)proteomes, published by various groups [16,17]. So far, all studies have examined low sample sizes (platelets from few subjects of mostly unknown gender); hence, questions about inter-subject variation and comparisons of subject cohorts remain to be answered [18-20].

Since 2011, with the improvement of mass spectrometric approaches, gradual progress has been made in unravelling the 'basic' platelet proteome and post-translational mod- 
ifications (Figure 1D). Markedly, there are a substantial number of studies interested in the ageing-related proteomic changes of in vitro stored platelets. The remaining works studied aspects of platelet signalling in response to key platelet receptors and agonists. As schematised in Figure 2, these concern signalling pathways via the collagen receptor glycoprotein VI (GPVI, ligands: collagen, collagen-related peptide CRP and convulxin); furthermore, signalling via the thrombin (co)receptors GPIb $\alpha$, PAR1 and PAR4 (ligands: thrombin, thrombin-receptor-activating peptides); the C-type lectin receptor CLEC-2 (ligands: podoplanin, rhodocytin); the ADP receptors $\mathrm{P}_{2} \mathrm{Y}_{12}$ and $\mathrm{P}_{2} \mathrm{Y}_{1}$; the thromboxane $\mathrm{A}_{2}$ $\left(\mathrm{TXA}_{2}\right.$ ) mimetic U46619 (a pathway inhibited by aspirin); and the platelet-inhibiting agents prostacyclin and nitric oxide.

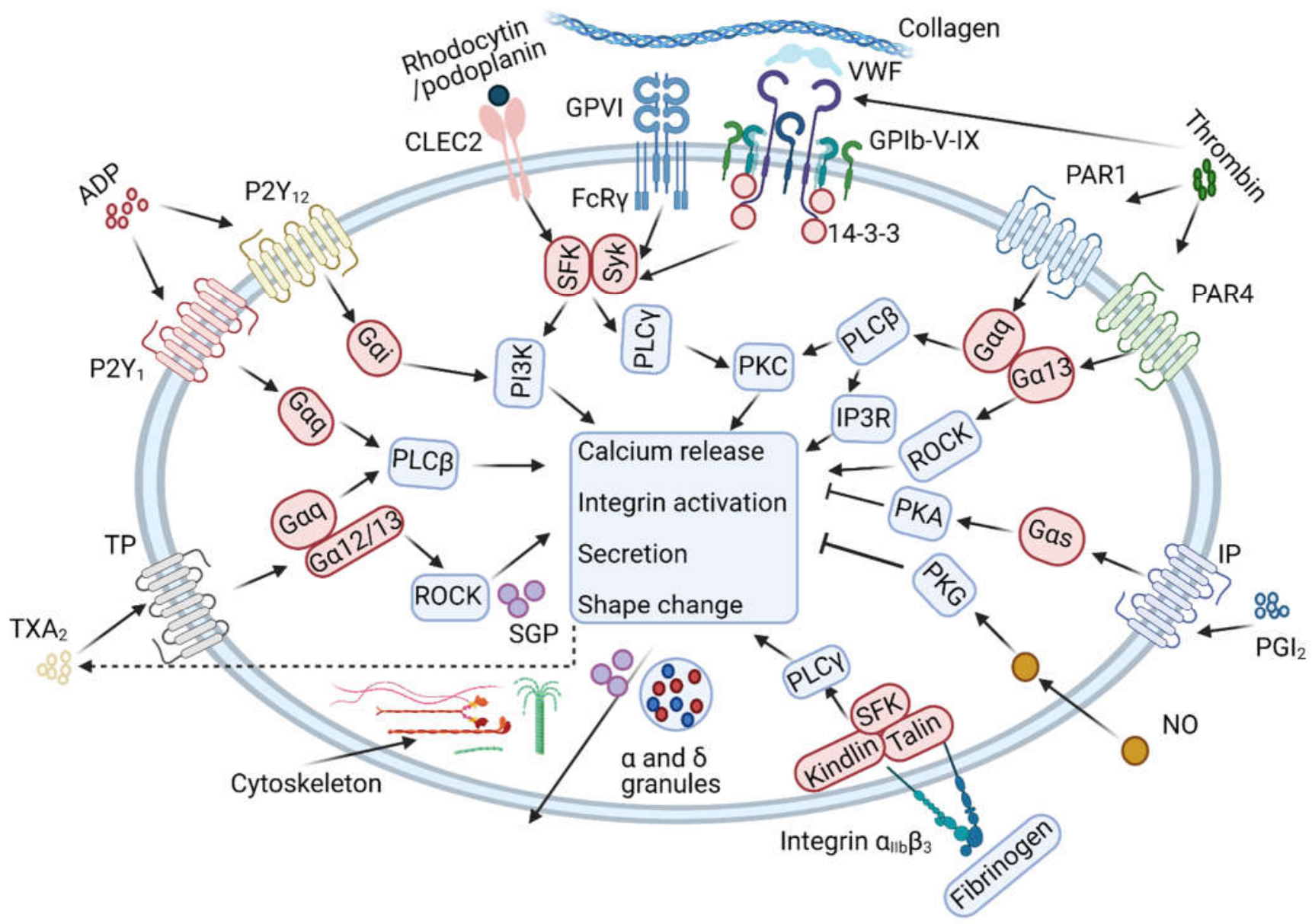

Figure 2. General overview of platelet signalling pathways. Overview of key platelet signalling and responses via key platelet receptors and agonists, examined by platelet proteomic analysis. Indicated are signalling via the collagen receptor glycoprotein (GP)VI, VWF receptor GPIb-V-IX; the proteinase-activated receptor (PAR)1 and PAR4 for thrombin; the podoplanin and rhodocytin receptor C-type lectin receptor 2 (CLEC2); the ADP receptors $\mathrm{P}_{2} \mathrm{Y}_{1}$ and $\mathrm{P}_{2} \mathrm{Y}_{12}$; thromboxane (TX) $\mathrm{A}_{2}$ mimetic $\mathrm{U} 46619$ (pathway inhibited by aspirin); integrin $\alpha_{\mathrm{IIb}} \beta_{3}$ outside/in signalling; actin and tubulin cytoskeletons; platelet-inhibiting prostacyclin $\mathrm{I}_{2}\left(\mathrm{PGI}_{2}\right)$ and nitric oxide $(\mathrm{NO})$; and $\alpha$-granule and $\delta$-granule secretion. Other abbreviations: G $\alpha$, heterotrimeric G proteins; PKA, PKC, PKG, protein kinases A, C, G; PLC, phospholipase C; SGP, small GTP-binding proteins; SFK, Src-family kinase. Refs. [2,5,21]. Originally created with BioRender.com accessed on 10 July 2021.

\section{Basic Platelet Proteome}

Based on genome-wide platelet transcriptome information, the theoretical platelet proteome (i.e., the number of expressed protein-encoding genes) is now estimated at $14.8 \mathrm{k}$ proteins. As far as we understand it now, particularly abundant in the identified platelet proteome are mitochondrial, metabolic, signalling/adaptor and transcription proteins [11]. In the past decade, significant progress has been made in establishing the 
protein composition of platelets freshly isolated from human blood samples. Numbers of proteins identified by mass spectrometry and by label-free analysis have increased from $1.3 \mathrm{k}$ in 2011 [22] to $5.4 \mathrm{k}$ [23], of which $3.7 \mathrm{k}$ are with estimated copy numbers [24]. Analysis of the 500 proteins with the highest copy numbers indicated the highest abundance of proteins in the actin and microtubule cytoskeletons, the $\alpha$-granules, involved in signalling, and (regulating) small GTPases [25]. Specific analyses indicated the abundant presence of nearly complete $20 \mathrm{~S}$ and $26 \mathrm{~S}$ proteasomes, implicating regular protein degradation [26]. A study of small and large platelets derived from the same healthy donor revealed that 80 proteins $(9 \%)$ differed in abundance [27]. These included signalling proteins, but also several plasma proteins (Table 2).

Table 2. Selection of protein changes in published platelet proteomes. Confined to papers showing abundant regulated proteins in platelet (fractions from) patients. Italic: plasma or secretory proteins [11].

\begin{tabular}{|c|c|c|c|}
\hline Aim of Study & $\begin{array}{l}\text { No. of Regulated } \\
\text { Proteins }\end{array}$ & Selection of Regulated Proteins & Ref. \\
\hline $\begin{array}{l}\text { 3-BASIC. Proteomes of large } \\
\text { and small platelets (1 subject) }\end{array}$ & 80 up or down (9\%) & $\begin{array}{l}\text { ADP-ribosylation factor } 1 / 3, \text { GTP-binding protein SAR1a, } \\
\text { guanylate cyclase soluble subunit } \alpha 3 \text {, voltage-dependent } \\
\text { anion channel protein } 3 \text {, serotransferrin, immunoglobulins, } \\
\text { haptoglobin, hemopexin, } \alpha 1 \text {-antitrypsin, vitronectin }\end{array}$ & [27] \\
\hline $\begin{array}{l}\text { 5-GPVI. Platelet proteome in } \\
\text { Scott syndrome ( } 1 \text { patient) }\end{array}$ & 134 up or down $(6 \%)$ & $\begin{array}{c}\text { anoctamin } 6 \text {, annexin A5, calpain } 1 \text {, protein } \mathrm{S} 100-\mathrm{A} 8 / 9, \\
\text { channel aquaporin-1, pregnancy zone protein, } \\
\text { myeloperoxidase, serine-pyruvate aminotransferase, } \\
\text { platelet glycoprotein } 4 \text {, cAMP-dependent } \\
\text { protein kinase II } \beta \text { regulatory subunit }\end{array}$ & [28] \\
\hline $\begin{array}{l}\text { 10-PAT. Platelet iloprost } \\
\text { phosphoproteome of PHP Ia } \\
\text { patients ( } 6 \text { patients) }\end{array}$ & 51 up or down $(11 \%)$ & $\begin{array}{l}\text { phosphorylation of protein kinase A consensus sites: } \\
\text { inositol triphosphate receptor associated } 1 / 2 \text {, bridging } \\
\text { integrator 2, vasodilator-stimulated phosphoprotein, } \\
\text { coiled-coil domain-containing protein } 9 \text {, claudin } 5 \text {, } \\
\text { consortin, Grb2-associated binding protein } 2 \text {. }\end{array}$ & [29] \\
\hline $\begin{array}{l}\text { 10-PAT. Platelet proteome in } \\
\text { X-linked thrombocytopenia ( } 5 \\
\text { patients) }\end{array}$ & 83 up or down $(4 \%)$ & $\begin{array}{l}\text { prostaglandin } \mathrm{G} / \mathrm{H} \text { synthase } 1 \text {, solute carrier family } 35 \\
\text { member D3, carbonic anhydrase } 2 \text {, peroxiredoxin } 1 \text {, } \\
\text { tubulin-tyrosine ligase-like protein } 12 \text {, spectrin } \alpha \text {-chain, } \\
\text { nexilin, E2 ubiquitin-conjugating enzyme, proteasome } \\
\text { subunit } \alpha / \beta \text { type } 4 \text {, heat shock } 70 \mathrm{kDa} \text { protein } 1 \mathrm{~b}\end{array}$ & {$[30]$} \\
\hline $\begin{array}{l}\text { 10-PAT. Platelet proteome in } \\
\text { Gray platelet syndrome ( } 5 \\
\text { patients) }\end{array}$ & 123 up or down (\% n.d.) & $\begin{array}{c}\text { neurobeachin-like protein } 2, \text { SPARC, serglycin, } \\
\text { latent-transforming growth factor } \beta \text {-binding protein } 1 \text {, } \\
\text { platelet basic protein, thrombospondin-1, platelet factor } 4 \text {, } \\
\text { multimerin-1, von Willebrand factor }\end{array}$ & [31] \\
\hline $\begin{array}{l}\text { 10-PAT. Platelet proteome of } \\
\text { patients with early-stage } \\
\text { cancer (12 patients) }\end{array}$ & 85 up or down $(3 \%)$ & $\begin{array}{l}\text { mitochondrial deoxyribonucleotidase and } 39 \text { S ribosomal } \\
\text { protein, V-type proton ATPase subunit S1, myomegalin, } \\
\text { serine/arginine repetitive matrix protein 2, CD34, } \\
\text { peptidoglycan recognition protein 1, nuclear } \\
\text { ribonucleoprotein A1, histone H2B type 1J, neurochondrin, } \\
\text { calmodulin-dependent protein kinase type 1D }\end{array}$ & [19] \\
\hline
\end{tabular}

Several mass spectrometry studies have examined the post-translational modifications of platelet proteins. For the identification of phosphoproteins, commonly a $\mathrm{TiO}_{2}$ sample enrichment step was used, often in combination with a calibration label, probe or antibody $[8,20,25]$. Reported changes in protein phosphorylation are discussed in the paragraphs below. In another enrichment protocol of platelet membranes, $0.2 \mathrm{k}$ palmitoylated proteins could be identified, among which was the TREM-like transcript-1 (TLT1) surface receptor [22]. Distinct enrichment protocols of specific platelet peptides identified $0.2 \mathrm{k}$ lysine methylations [32] and $1.6 \mathrm{k}$ neo N-termini [28,33], indicating that protein methylation and cleavage play vital roles in normal platelet function. In a study of unclear physiological significance, a $5.4 \mathrm{k}$ platelet proteome was reported, of which $\sim 10 \%$ was regulated by the 
serotonin antagonist sarpogrelate [23]. However, the precise role of serotonin in platelet activation still needs to be defined [34]. Reported limitations of the various studies are the unclear relations of the newly identified platelet proteins and the low numbers of proteomes analysed (Table 1).

\section{Proteome Changes in Ageing Platelets}

The preferred way to store (ageing) platelets for best preservation of their functions after transfusion is a long-standing issue [35]. Transcriptome-based studies indicated that freshly isolated platelets have a limited capacity for protein synthesis, along with ongoing degradation of RNA species [36]. Commonly, platelet concentrates for transfusion purposes can be stored for multiple days, after which the platelets start to lose functional properties, a phenomenon known as platelet storage lesion [37]. To investigate the cause of this lesion, multiple studies have been carried out on the protein changes of ageing platelets. Since 2018, label-free quantification methods have been used in particular (Table S1).

An early paper assessed the extent of protein degradation by determining $\mathrm{N}$-terminal methionines (i.e., formed by acetylation or endo-proteolysis) [33]. It was reported that the majority $(77 \%)$ of $2.9 \mathrm{k}$ identified proteins contained neo N-termini, which suggested extensive proteolytic processing during platelet storage. Matrix metalloproteinases were found to play an important role in this neo $\mathrm{N}$-terminus formation, pointing to a continued protein cleavage in the platelet granules and in other membrane vesicles. In a platelet apheresis intervention protocol to enrich younger circulating platelets (one donor and $1.0 \mathrm{k}$ identified proteins, hence low power), it was reported that endocytosis- and cytoskeletonrelated proteins changed with the platelet age [38].

Some studies compared the ageing of platelets in different storage media, using 2D gelbased or pre-labelled proteomic techniques [39]. While differences in several proteins were observed between storage arms of the studies, the relationship with changes in platelet functions were not always clear. Two quantitative proteomic analyses indicated that, with increasing storage time, modified proteins especially had a role in degranulation $[13,40]$. Platelets stored in the cold at $2-6^{\circ} \mathrm{C}$ were found to express reduced levels of glycoproteins and increased levels of surface activation markers, likely due to stimulation of glycoprotein shedding [41], but the cold storage did not affect platelet viability [40]. An induction of platelet degranulation was caused by pathogen inactivation technologies (e.g., with Mirasol) before storage [42].

A number of groups have been searching for platelet proteins that can explain adverse transfusion reactions affecting the patient's health after the transfusion of ageing platelets. Regarding pathogen inactivation, treatment of platelet concentrates with riboflavin and ultraviolet light for two days - producing reactive oxygen species-resulted in slight increases in oxidised peptides, when compared to the $18 \%$ of $9.4 \mathrm{k}$ identified platelet peptides that were oxidised anyway $[43,44]$. Proteomic studies on extracellular vesicles formed from ageing platelets revealed that metabolic proteins (e.g., glycolysis and lactate production) and proinflammatory cytokines (CCL5, PF4) were upregulated upon ageing [45]. A comparison of pooled platelet concentrates and single-donor apheresis platelets-both of which are preparations that occasionally trigger adverse transfusion reactions-revealed a partly common set of proteome changes (i.e., granular and mitochondrial proteins). On the other hand, signalling pathway analysis also revealed some differences: altered integrin $\alpha_{\mathrm{IIb}} \beta_{3}$ signalling in the pooled concentrates and acute phase response pathways in the apheresis platelets [46,47].

\section{Collagen Receptor Glycoprotein VI (GPVI)}

GPVI is a key collagen and fibrin receptor on platelets ( $3-4 \mathrm{k}$ copies per cell), which signals via a cascade of protein tyrosine kinases, leading to strong platelet activation [48,49]. GPVI interaction with subendothelial collagens induces arterial thrombus formation upon vascular injury, as confirmed in multiple in vivo studies with genetically modified mice and in microfluidics studies with mouse or human blood [50,51]. At high wall shear rates, 
this interaction is preceded by platelet adhesion to von Willebrand factor (VWF), which avidly binds to collagens, via the GPIb-V-IX complex [52].

Platelet GPVI binding to collagens and to a lesser extent fibrin induces a profound activation cascade, initiated by tyrosine phosphorylation of immunoreceptor tyrosine-based activation motifs (ITAM) in its co-receptor Fc receptor $\gamma$-chain $(\mathrm{FcR} \gamma)$, which ultimately leads to platelet aggregation, secretion and procoagulant activity $[5,53]$. The signalling pathway involves Src-family kinases (SFK) and the spleen tyrosine kinase Syk, which triggers the activation of multiple signalling enzymes and adaptors, such as Btk/Tec family kinases, LAT, SLP76, phospholipase C $\gamma 2$ (PLC $\gamma 2$ ) and PI3 K isoforms (Figure 2) [54]. As GPVI-deficient patients experience variable but mostly not severe bleeding episodes, this underscores the concept of a more prominent role of GPVI in arterial thrombosis than in haemostasis [55,56].

First studies using gel spots to identify phosphorylated signalling targets resulted in only small sets of differentially regulated proteins linked to GPVI-induced platelet activation (Table S1) $[57,58]$. However, in a recent GPVI phosphoproteome paper, $>3.0 \mathrm{k}$ phosphorylation events ( $>1.3 \mathrm{k}$ proteins) were identified by tandem mass tag (TMT) labelling and triple-stage tandem mass spectrometry. With literature-guided causal inference tools, more than $0.3 \mathrm{k}$ site-specific signalling proteins could be obtained, among which were key and emerging GPVI effectors (i.e., Fc $\gamma R$, Syk, PLC $\gamma 2$ and DAPP1) [59]. Interesting is the phosphorylation identification, downstream of GPVI, of a wide panel of small GTP-binding proteins (Ras and Rab GTPases) and activities of MAPK pathways [59]. The higher GPVIinduced platelet aggregation in patients with myocardial infarction was accompanied by increased phosphorylation of several of these signalling proteins [60]. Similarly, $\sim 0.2 \mathrm{k}$ basal phosphorylation sites were upregulated in platelets from obese patients, which were associated with augmented platelet adhesion to collagen [61].

Proteomic studies also focussed on other post-translation modifications. Thus, a procedure to assess reversible protein acetylation found $0.6 \mathrm{k}$ acetyl-lysine residues $(0.3 \mathrm{k}$ proteins) serving as substrates for lysine acetyltransferases, which seem to be regulated in response to GPVI activation and subsequent cytoskeletal changes [62]. Another study detected $0.8 \mathrm{k}$ extra-cytosolic $\mathrm{N}$-linked glycosylation sites with some of these regulated by GPVI [63]. This agrees with the finding that glycan glycosylation plays a role in plateletcollagen interaction [64]. In GPVI-stimulated platelets, it appeared that $0.9 \mathrm{k}$ out of $1.6 \mathrm{k}$ ubiquitinylated peptides (corresponding to $0.7 \mathrm{k}$ proteins, including Syk, filamin and integrins) were upregulated, implicating a profound role of GPVI in the ubiquitin protein degradation pathway [65]. To what extent proteins are degraded after GPVI stimulation is still unclear.

Lipidomic mass spectrometry of complexed phosphoinositides and bound proteins showed that upon PI3K activation, many proteins can interact with 3-phosphorylated phosphoinositides through their $\mathrm{PH}$ domains, among which is the new adaptor protein DAPP1 [66]. Membrane lipid rafts of GPVI-stimulated platelets were also analysed in detail [67]. Oligophrenin as a small GTPase-binding protein regulator was furthermore recognised as a functional target of the GPVI-induced tyrosine kinase cascade [68]. To what extent secondary mediators (ADP, $\mathrm{TXA}_{2}$ ) contribute to the GPVI-induced proteome changes has not systematically been investigated.

Stimulation via GPVI—enforced by thrombin —is an exemplary condition to evoke platelet procoagulant activity $[69,70]$. This response induced by a prolonged cytosolic $\mathrm{Ca}^{2+}$ elevation, ballooning and phosphatidylserine exposure allows the assembly and activation of coagulation factors on the platelet surface [71]. Proteomic studies have contributed to better understand these GPVI-mediated platelet responses. This held for platelets from a patient with Scott syndrome, i.e., a rare bleeding disorder with autosomal recessive mode of transmission. In the patient's platelets, lacking phosphatidylserine externalisation due to a mutation in the ANO6 gene, the corresponding protein was found to be absent along with a reduction in calpain-like proteins [28]. The latter observation could explain a reduced cytoskeleton cleavage and a prolonged agonist-induced phosphorylation pattern $(1.6 \mathrm{k}$ 
phosphopeptides) in response to GPVI + PAR stimulation or ionomycin. Of the identified proteins, $6 \%$ were found to be up- or downregulated in the patient platelets, among which were several membrane glycoproteins (Table 2).

\section{Signalling C-Type Lectin Receptor 2 (CLEC-2)}

The hem-ITAM-linked receptor CLEC-2 triggers multiple platelet activation processes, with podoplanin as a known ligand in the lymphatic system, but no clear ligand in the blood or healthy blood vessels. On the other hand, platelet CLEC-2 has been recognised as a key receptor in thrombo-inflammatory disorders [72]. Similarly to GPVI, activation of CLEC-2 triggers a tyrosine kinase cascade, resulting in SFK and Syk activation via a hem-ITAM domain (Figure 2). Downstream signalling routes involve PLC $\gamma 2$, Tec and PI3K family members $[73,74]$. A laboratory ligand of CLEC-2 is the snake venom rhodocytin.

Several platelet proteomic studies have helped to further resolve CLEC-2-induced signalling pathways. In rhodocytin-stimulated platelets, following gel separation and phosphoprotein enrichment, $0.1 \mathrm{k}$ proteins of the broad signalosome were identified next to the expected ones, including the novel adapters Dok2 and ADAP, the tyrosine kinase Fer and the phosphatase SHP1 [75]. This study also revealed subtle differences between the CLEC-2 and GPVI signalling routes.

Another study of the protein composition of membrane lipid rafts found large similarities after platelet stimulation via CLEC-2 or GPVI [67]. Intriguing is an observed loss of cytoskeletal proteins in the rafts from the activated platelets. Extended analysis of the rhodocytin-stimulated phosphoproteome revealed a large panel of $0.4 \mathrm{k}$ regulated phospho-tyrosine residues, among those multiple signalling and adaptor proteins, protein kinases and membrane-associated proteins [20]. Similar to the GPVI-induced activation, platelet stimulation via CLEC-2 relies on autocrine feed forward processes via released ADP and TXA $2[20,21]$. Exactly which (phospho)proteome changes are dependent on these second mediators is still unclear.

\section{Thrombin and Protease-Activated Receptors (PAR1, PAR4)}

The serine protease thrombin cleaves coagulation factors, producing fibrin fibres from fibrinogen, and it also cleaves platelet protease-activated receptors (PARs) [76,77]. On human platelets, thrombin cleaves and activates the G $\alpha$ q-protein-coupled receptors PAR1/4, while thrombin has an additional minor stimulatory role through its binding to the GPIb-V-IX complex [78]. PAR1 is the receptor operating at low thrombin concentrations, while PAR4 becomes activated at higher agonist concentrations [77]. The classical G $\alpha \mathrm{q}$ pathway leads to activation of phospholipase C $\beta$ (PLC $\beta$ ), which like PLC $\gamma 2$ hydrolyses phosphatidylinositol 4,5-bisphosphate into the second messengers inositol trisphosphate $\left(\mathrm{IP}_{3}\right)$ and diacylglycerol [5]. The formed $\mathrm{IP}_{3}$ induces via $\mathrm{IP}_{3}$ receptors the endoplasmic reticular release of $\mathrm{Ca}^{2+}$, while diacylglycerol stimulates protein kinase $\mathrm{C}$ (PKC) isoforms and the signalling mediator CalDAG-GEFI $[79,80]$. Granule secretion and aggregation are important responses of thrombin receptor-stimulated platelets. In addition, PARs can couple to G $\alpha 13$ [81], which leads to activation of RhoA and Rho kinase (ROCK) via small GTP-binding proteins, and mediates platelet shape change and low-dose thrombin-induced aggregation [82].

After activation or ageing, platelets lose part of their constituents to the environment in several ways, i.e., by granular secretion, extracellular vesicle (microparticle) formation and receptor shedding [77]. Together, the lost proteins are termed as the releasate proteome [83]. Mass-spectrometric studies have examined the (granular) content of platelet releasates (Table S1). For a set of $0.1 \mathrm{k}$ proteins, differences were reported between the PAR1- and GPVI-induced platelet releasates [84]. Among a broader set of $0.7-0.9 \mathrm{k}$ proteins, $\sim 10 \%$ seemed to be over- or under-represented in the platelet releasate from pregnant women $[85,86]$. However, the studies report various limitations, including low sample numbers and unclear clinical relevance (Table 1). 
Next to the released secretome, the composition of PAR-induced extracellular vesicles (microparticles) was also analysed by mass spectrometry. For a set of $3.4 \mathrm{k}$ proteins $(0.4 \mathrm{k}$ membrane proteins), it was found that thrombin induces the release of extracellular vesicles that are enriched in proteins sensitive to platelet activation, with an underrepresentation of granular proteins [87]. Examination of the platelet-derived extracellular vesicles from obese individuals showed expression changes in mitophagy and antioxidant defence proteins, when compared to non-obese subjects [88].

A pioneering paper in 2004 identified 62 differentially regulated protein features in PAR1-stimulated platelets [89]. A later report on a $3.4 \mathrm{k}$ platelet proteome mentioned abundance changes in $>20 \%$ of the proteins after PAR stimulation [18], a finding that will need further confirmation and explanation. In a focussed study, thrombin-induced Dab2 phosphorylation could be linked to platelet aggregation and ADP release [90]. Another report showed that inter-individual changes in the activated platelet proteome are related to miRNA levels [91]. This is one of the rare proteomic papers so far mentioning interindividual variation.

\section{Aspirin and Thromboxane $\mathrm{A}_{2}$}

Several primary platelet agonists evoke release of the autocrine agent thromboxane $\mathrm{A}_{2}$, which is formed from arachidonate in phospholipids and is converted by the cyclooxygenase 1 (COX1)-thromboxane synthase complex [2,92]. Aspirin, the most common antithrombotic drug, irreversibly blocks the cyclooxygenase and hence the thromboxane synthesis. The platelet thromboxane receptor couples to the $\mathrm{G} \alpha \mathrm{q}$ and $\mathrm{G} \alpha 13$ proteins, which results in PLC $\beta$ and ROCK activation, respectively [93]. The latter mediates the RhoA-dependent platelet shape change.

Interesting proteomic observations have been made in this context (Table S1). Using a label-free proteomic approach, platelets obtained from cord blood, which relatively poorly respond to thromboxane stimulation, express normal receptor levels, but are enriched in mitochondrial energy and metabolism proteins, including NDUFS1, NDUFA10, NDUFAS and NDUFY2 [94]. A perhaps accidental finding due to low sample size was that platelets from good and poor responders to aspirin treatment were differentiated in the level of carbonic anhydrase II [95].

Some reports have more extensively examined the effects of aspirin on platelets, considering that this drug can $\mathrm{N}$-acetylate not only the thromboxane synthase complex, but also other many proteins. In an iTRAQ labelling study of the platelet glycoproteome, a small subset of the $0.8 \mathrm{k}$ identified N-linked glycosylation sites was affected by aspirin treatment, among which was the secretory protein TIMP1 (metallopeptidase inhibitor 1) [63]. Furthermore, in a listing of $3.3 \mathrm{k}$ acetylated residues, $6 \%$ showed aspirin regulation, with a higher acetylation state in the platelets from diabetic patients [96]. A pilot report stipulated that the lower aspirin effects on platelets from diabetics was linked to the glucose-suppressed glycation of in particular COX1 [97].

\section{ADP Receptors and Platelet Inhibitors}

ADP is another important secondary mediator that is released from granules after initial platelet activation, and ensures the formation of platelet aggregates and thrombi $[5,98]$. ADP itself activates platelets through the G-protein coupled P2 $Y_{1}$ and $P 2 Y_{12}$ receptors to trigger different downstream pathways. The $\mathrm{P}_{2} \mathrm{Y}_{1}$ receptors support the first reversible phase of ADP-induced platelet aggregation, while the P2 $\mathrm{Y}_{12}$ counterparts function to consolidate this aggregation. The only lowly expressed $\mathrm{P}_{2} \mathrm{Y}_{1}$ receptors evoke a G $\alpha \mathrm{q}$-mediated signalling route via PLC $\beta$, cytosolic $\mathrm{Ca}^{2+}$ elevation and PKC, such as that described for PAR1, but weaker in strength [80]. The P2 $\mathrm{Y}_{12}$ receptors are G $\alpha \mathrm{i}$ coupled, activate PI3K forms and prevent adenylate cyclase to synthesize cAMP [98].

An 'opposite' pathway leading to platelet inhibition is triggered by the endothelialderived prostacyclin (prostaglandin $\mathrm{I}_{2}$ ). Via a receptor on platelets, prostacyclin (or analogue iloprost) couples to G $\alpha$ s (GNAS gene), which activates adenylate cyclase and in- 
creases cAMP $[29,93]$. The second messenger cAMP induces phosphorylation events by the broad-spectrum protein kinase A (PKA). In this way, prostacyclin can antagonise almost all platelet activation responses, including secretion, aggregation and procoagulant activity $[2,99,100]$.

Proteomic-based studies were performed to better understand the antagonistic roles of ADP and prostacyclin (iloprost) by the analysis of (partly reversible) protein phosphorylations (Table S1). Using a quantitative labelling method for analysis of time-resolved phosphorylation changes ( $13 \%$ of $2.7 \mathrm{k}$ phosphopeptides), it was concluded that platelet inhibition with iloprost is a multipronged process involving a broad spectrum of protein kinases and phosphatases, ubiquitinated proteins and many structural proteins [101]. Over 100 direct or indirect PKA targets were identified, revealing that platelets are inhibited by network-connected multiple signalling pathways [101]. Using the method of stable-isotope iTRAQ labelling (Figure 3), it was furthermore found that iloprost reverted $17 \%$ of the $0.4 \mathrm{k}$ regulated phosphorylation sites (out of $3.6 \mathrm{k}$ phosphopeptides) of ADPstimulated platelets [102]. Dual-regulated phosphoproteins included signalling proteins and degranulation-regulating proteins, which in part were identified as targets of PKA or PKC.

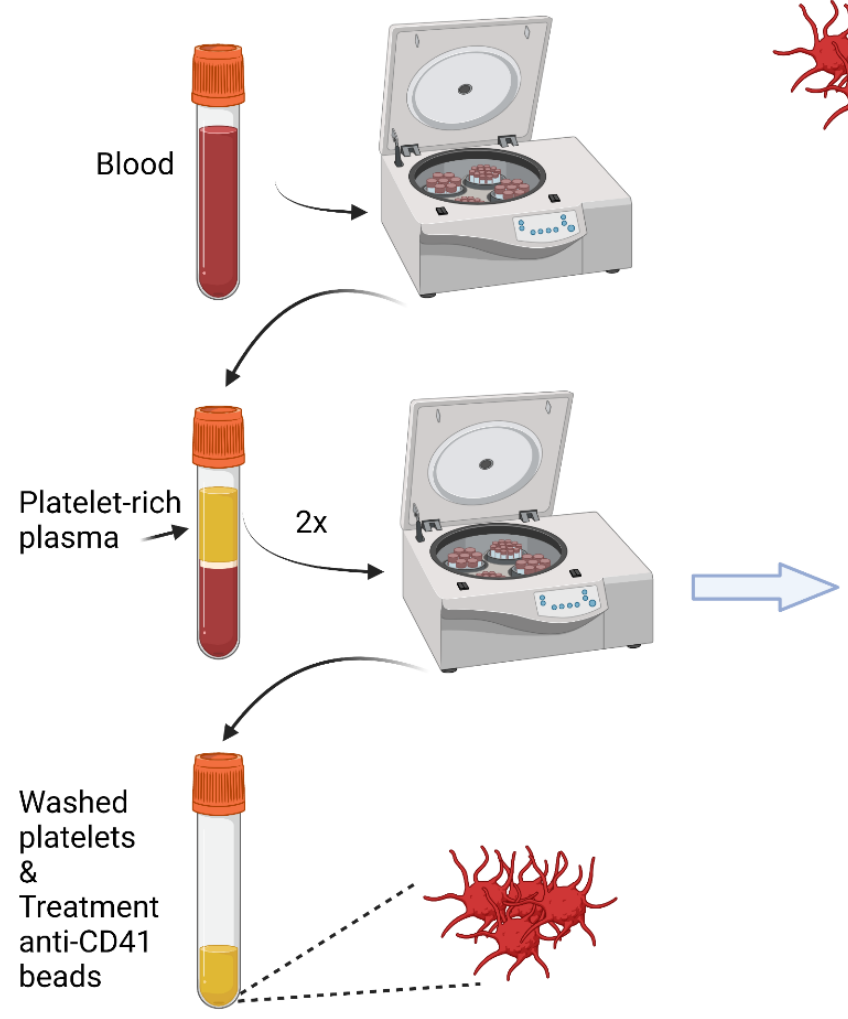

(A)
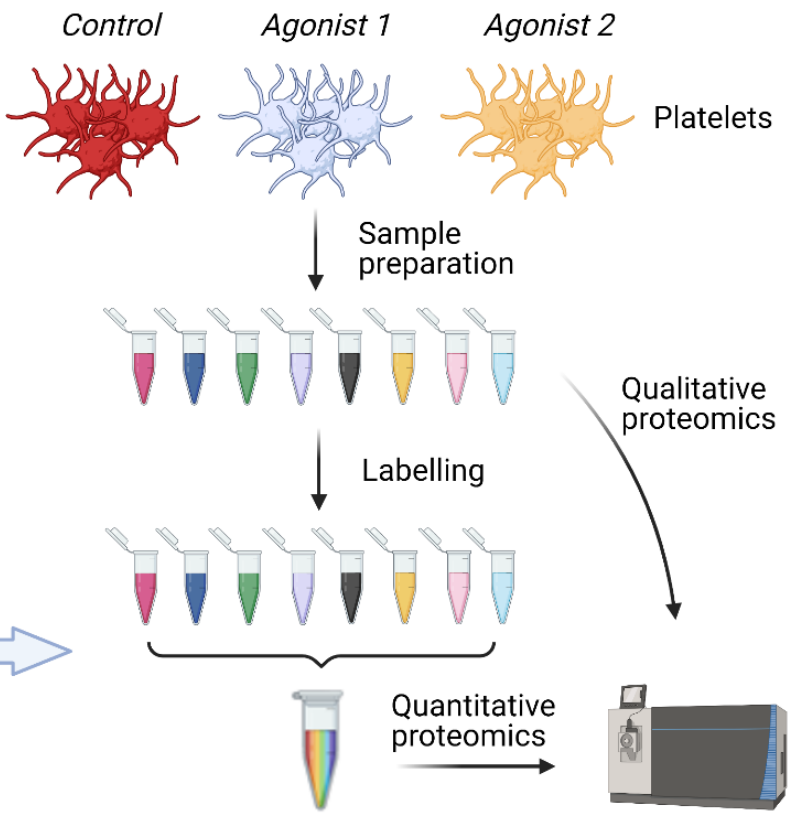

Enrichment

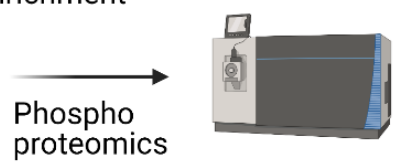

Figure 3. Global protocol of combined proteome analysis of (un)stimulated platelets. (A), Human platelet isolation from freshly drawn blood. Platelet-rich plasma (PRP) is collected by centrifugation and then re-centrifuged twice to obtain double-washed platelets. Removal of remaining leukocytes' antibody-coated beads is advised. Platelet purity is determined by flow cytometry or microscopy. (B), Isolated platelets are stimulated with agonists as required. After lysis, proteins are fragmented by trypsin under well-controlled conditions, in this case in the presence of unique stable isotope labels. Pooled, labelled samples are fractionated, and peptides are resolved by LC-MS/MS analysis. For quantitative proteome information, reference peptides can be added. In case of phosphoproteome analysis or other post-translational modifications, an enrichment step is included for improved detection. An example protocol is provided in Box 1. Created with BioRender.com. 
Box 1. Example workflow for bottom-up proteomic analysis of platelets.

(i) Platelet preparation. Citrate-anticoagulated whole blood is centrifuged at $280 \times g$ for $10 \mathrm{~min}$, to obtain platelet-rich plasma (PRP), the upper part of which is then centrifuged at $80 \times g$ for $10 \mathrm{~min}$ in the presence of anticoagulant medium [29] to pellet leukocytes. After pelleting the platelets (380 $\times$ $g$ for $10 \mathrm{~min}$ ), the pellet is resuspended in buffer medium plus anticoagulant and apyrase. Another centrifugation step then gives washed platelets, which are resuspended in albumin-free buffer medium $\left(\geq 5 \times 10^{8} / \mathrm{mL}, \geq 1.0 \mathrm{mg}\right.$ protein $/ \mathrm{mL}$ ). Leukocytes are counted preferably by microscopy, and immune depletion is applied if needed. The platelet suspension is left standing for 15-30 min. Samples (50-200+ $\mu \mathrm{g}$ protein) are stimulated by agonists as required, and stopped by addition of $4 \times$ concentrated lysis buffer ( $4 \%$ SDS, $150 \mathrm{mM} \mathrm{NaCl}, 50 \mathrm{mM}$ Tris, pH 7.4, PhosStop added). Samples are frozen in liquid nitrogen and stored at $-80^{\circ} \mathrm{C}$.

(ii) Peptide sample preparation. For in-solution digestion, the platelet proteins are reduced and alkylated in lysis buffer. Then, the lysis buffer is replaced by digestion buffer, and trypsin added to digest overnight. For relative quantification, isotopic reagents iTRAQ or TMT are used to label peptides. If needed, suitable enrichment methods are used, e.g., to concentrate phosphopeptides. RP-HPLC is commonly used to separate whole peptide mixtures, and hydrophilic interaction chromatography (HILIC) to separate phosphopeptides. Fractions are desalted to remove contaminants and detergents.

Recently, such studies were extended to nitric oxide, another major endothelialderived potent platelet inhibitor [103,104]. Nitric oxide, as an unstable, membranepermeable gas, increases platelet cGMP via guanylate cyclase, which produces protein kinase G (PKG) [104,105]. The formation of nitric oxide by platelets themselves via nitric oxide synthase is not likely [101]. Via a battery of cAMP/cGMP-dependent phosphodiesterases, the two cyclic nucleotides-and hence PKA and PKG activities—are 'communicating'. The antagonism of platelet inhibitors (prostacyclin, nitric oxide) and platelet stimulators (ADP, thrombin, collagen) has led to phosphoproteomic analysis to identify protein phosphorylation events that determine the switch between inhibition and activation [106]. Herein, cross-talk signalling mechanisms were discovered, such as a feedback regulation of Syk by PKC [107]. It was also found that CLEC-2 activation triggers via ADP- and thromboxane the phosphorylation of a core set of signalling proteins (e.g., Src, PLC $\gamma 2$ ) [20].

\section{Platelet Proteomics of Patients with Platelet Defects or Cardiovascular Disease}

Only limited proteomic studies have appeared on the changes in protein (modification) patterns of patients with platelet-related disorders (Table S1). The few examples are patients with Glanzmann's thrombasthenia (lacking integrin $\alpha_{\mathrm{IIb}} \beta_{3}$, mutated ITGA2B), Scott syndrome (mutated phospholipid scramblase ANO6), X-linked thrombocytopenia (GATA1 mutation), pseudohypoparathyroidism type Ia (PHP Ia, mutated GNAS locus) and Gray platelet syndrome (mutated NBEAL2, $\alpha$-granule deficiency).

Targeted mass spectrometry confirmed that, for platelets from patients with type I Glanzmann thrombasthenia (a severe bleeding disorder), the level of integrin $\alpha_{\mathrm{IIb}}$ was greatly reduced to $<5 \%$ of control subjects [108]. In addition, plasma proteins endocytosed by integrin $\alpha_{\mathrm{IIb}} \beta_{3}$, such as fibrinogen, factor XIII, plasminogen and carboxypeptidase $2 \mathrm{~B}$, appeared to be downregulated when compared to the control platelets. Upregulated was the immunoglobulin receptor Fc $\gamma$ RIIA, and in one patient the tetraspanin CD63 after Fc $\gamma$ RIIA crosslinking, while the granular proteins were normal. Extensive global, phosphoand N-terminal proteome analysis was performed on platelets from a Scott patient (a rare, mild bleeding disorder), characterised by failure of agonist-induced phosphatidylserine exposure and procoagulant activity [109]. In the patient's platelets, quantitative proteomics revealed a spectrum of $134(6 \%)$ up- or downregulated proteins [28], including complete absence of the phospholipid scramblase anoctamin- 6 and low calpain-1 protease (regulating platelet morphology changes) (Table 2). Interestingly, the cell-volume-regulating protein aquaporin-1 was upregulated, putatively as a compensatory mechanism.

A mutation in exon 4 of the GATA1 gene is associated with X-linked thrombocytopenia with thalassemia (OMIM 314050), which is a severe bleeding disorder. Quantitative 
proteomics of the platelets from five male patients revealed 83 altered proteins [30]. Among these were COX1 plus several cytoskeleton and proteasome proteins (Table 2). In comparison, in platelets with mutant GATA binding factor 1, more than 300 proteins were proposed to be differentially expressed in comparison to control subjects [110].

In 5 out of 47 Gray platelet syndrome patients (a milder bleeding disorder) with new variants in NBEAL2, 123 platelet proteins were mostly downregulated, with the majority being $\alpha$-granule-associated and cargo proteins at unaltered mRNA expression levels (Table 2) [31]. Markedly, plasma proteins related to immune responses and inflammation were upregulated, which suggested the presence of an immune defect in these patients as well. In the platelets from five patients with PHPIa (Albright hereditary osteodystrophy, a disease of hormonal resistance and abnormal postures, no bleeding), quantitative phosphoproteomics revealed $0.5 \mathrm{k}$ iloprost-regulated phosphorylation sites [29]. In agreement with a loss-of-function of $\mathrm{G} \alpha$ s in the patient's platelets, a panel of 51 phosphorylated proteins was identified that showed a consensus PKA phosphorylation site and that was altered in most of the patients (Table 2).

In addition to these rare congenital abnormalities, few proteomic studies have examined platelets from patients with somatic mutations (cancer) or genetically less well-defined diseases. In a study on platelets from 12 patients with early-stage cancers (in comparison to healthy subjects), quantitative proteomic analysis indicated disease regulation of a wide variety of $85(3 \%)$ proteins (Table 2), the majority of which normalised after surgical resection [19]. Some of the regulated proteins may be useful as biomarkers for such cancers. This area requires further attention.

Analysis of the platelet proteome of patients with progressive multiple sclerosis showed elevated levels of plasma proteins such as fibrinogen and $\alpha_{2}$-macroglobulin [111], pointing to increased endocytosis or stickiness of the patient platelets. In patients infected with dengue virus, platelet quantitative proteomics identified about $0.3 \mathrm{k}$ regulated proteins [112]. With the aim to find a biomarker related to Alzheimer's disease, proteomic analysis of platelets from patients with mild and severe cognitive function revealed 360 differentially regulated proteins. Four of these (PHB, UQCRH, GP1BA and FINC) were able to distinguish patients from healthy controls [113]. However, the link to disease is still unclear.

A few studies examined the platelets from patients with cardiovascular diseases (Table S1). Differentially regulated proteins were identified in the platelets from two groups of patients with (acute) coronary syndrome; there were, in particular, signalling, glycolysis and cytoskeletal proteins $[114,115]$. In patients experiencing ST-elevation myocardial infarction (STEMI), gel-based proteomics identified 16 altered proteins in platelets that were collected at the intracoronary culprit site, including integrin $\alpha_{\mathrm{IIb}}$ and thrombospondin-1, in comparison to the circulating platelets [116]. Additionally, in STEMI patients, platelet phosphoproteomic analysis revealed an increase in key tyrosine phosphorylations in response to GPVI stimulation, which raised the possibility of GPVI as an antithrombotic target in STEMI $[84,116]$. Only a few altered proteins were found in the platelet releasate of patients with stable angina pectoris [117], and in whole platelets from patients with lupus anticoagulant-related thrombosis [118], along with evidence for increased platelet activation. Additionally, in hyperlipidaemia, the platelet proteome was found to be markedly unchanged [119]. Semi-quantitative workflows were developed to find platelet-related protein biomarkers in cardiovascular disease [120].

\section{Practical and Technical Considerations}

Platelet preparation. In current platelet proteomic research, washed platelets are commonly used. As indicated in Figure 3, the platelet isolation protocol is usually based on a series of centrifugation steps to separate platelets from other blood cells and plasma. In Box 1, we provide a validated protocol based on our own experience. However, given the presence of an extended open canicular system in platelets in direct contact with the blood plasma, residual plasma proteins are invariably seen in most listed platelet proteomes [11]. 
The reviewed papers show a wide variety of platelet purities, platelet concentrations and amounts of proteins used per analysed sample (Table S1). Furthermore, the procedure to use platelets at a resting state is important; this can be evaluated by flow cytometry (e.g., checking for integrin $\alpha_{\mathrm{IIb}} \beta_{3}$ activation and P-selectin expression) or by parallel-reaction monitoring (PRM) tests [102]. It is of no doubt that all these variables can influence the composition and size of an established platelet proteome, and that standardisation is therefore needed (Box 1). The agonists and ways to activate platelets are other matters of variation, as seen between papers, in that most agonists indirectly trigger secondary pathways via release of ADP, TXA 2 and other autocoids [2]. This is very likely to affect (time courses of) phosphorylation outcomes [102].

The complexity of platelet proteome analysis is increased by a wide variety of posttranscriptional protein modifications (protease processing, acetylation, acylation, phosphorylation and glycosylation) [8,9]. In our experience, new mass spectrometry acquisition techniques such as data-independent acquisition make it easier to quantify low-abundance (post-translated) protein forms.

Peptide sample preparation. At present, sample preparations for bottom-up proteomics analyses (no prior gel separation) is the most common technique. For the collection of trypsin-digested peptides, filter-aided sample preparation, S-trap-based digestion methods and ethanol precipitation are preferred [121,122]. Novel proteomic approaches at the horizon are a nanodroplet processing platform for analysis of small cell numbers [123].

For higher throughput purposes, label-free analysis can be performed [13], where unlimited sample numbers can be compared at the proteome level. Another ratioed method makes use of stable isotope sets, such as in iTRAQ- and TMT-based quantification, where up to 16 (phosphopeptide) samples are pooled together [29,63]. Prior enrichment methods for phosphopeptides relied on metal oxide affinity chromatography with titanium dioxide $\left(\mathrm{TiO}_{2}\right)$ beads $[24,28,102]$. An alternative is provided by immobilized metal affinity chromatography (IMAC) with liquid handling systems, which allow phosphopeptide enrichment of up to 96 samples at the same time [124].

Data analysis. The most commonly used strategy for proteomic data analysis is searching against established fragmentation spectra databases. A helpful overview of current bioinformatics methods for protein identification and quantification is given in [125]. An important step in the analysis is data normalization, where corrections according to specific rules are applied to remove inconsistent data points, followed by statistical tests (checking for false discovery rates). Regarding phosphoproteomics, data normalization is also necessary because the apparent regulation of a phosphorylation site should not be caused by an altered protein abundance [126]. Special algorithms have to be employed for assessing the phosphorylation position and the responsible kinase of a phosphorylated peptide [29].

Current limitations. Many of the publications indicated as a limitation the use and comparison of only a few platelet samples (Table 1). This has made it difficult to draw conclusions on inter-subject variation, even when comparing healthy subjects with patients. Technical limitations include low peptide coverage linked to low protein abundance, complex spectral data analysis, missing (hydrophobic) peptide sequences and unclear function of many discovered proteins [8].

\section{Future Perspectives and Challenges Ahead}

Over the last 20 years, the field of platelet proteomics has evolved rapidly, from the early 2D gel electrophoresis studies to the more recent bottom-up-based ones. The evolution of recent generations of mass spectrometers has allowed protein quantitative studies and the elucidation of complex phosphorylation patterns of proteins with often still unknown functions. Enrichment steps, for instance, to concentrate negatively charged peptides from trypsin-treated lysates, and advanced sample preparation protocols are now bypassing the earlier gel separation steps. 
As shown in this review, the new proteomic methods have led to a gradual enlargement of the human molecular platelet (phospho)proteome, thus identifying so far up to $6 \mathrm{k}$ identified proteins ( $3.7 \mathrm{k}$ with copy numbers), which however are only partly linked to known platelet functions. The platelet phosphoproteome contains up to $5 \mathrm{k}$ phosphorylation sites with many sites altered upon platelet stimulation (via GPVI, PARs, CLEC-2, ADP) or platelet inhibition (with iloprost). The regulated Ser/Thr and Tyr phosphorylation sites included not only the known or expected signalling proteins, but also a multitude of poorly understood signalling, regulatory, structural and metabolic proteins. Diverse sets of previously known and new proteins were found to be altered in pathological situations, but the 'regulation' of these was mostly not confirmed in independent studies. As described above, advances in the proteomic field have also led to the identification of (novel) platelet proteins as potential biomarkers for disease.

Accordingly, proteomics has been developed as a fundamental tool for platelet research. On the other hand, it is time now to consider how to turn this field from the phase of discovery into the phase of biological and (pre)clinical application. The analysis of 70 papers in the present review has taught us that for this transition, a number of challenges are ahead. These can be grouped into the following eight points.

Despite the broad heterogeneity in mass spectrometry and spectral analysis methods, the precise composition of the 'normal' human platelet proteome is still unclear. While the theoretical proteome recently could be deduced from the genome-wide platelet transcriptome of $14.8 \mathrm{k}$ protein-encoding transcripts [11], published papers so far show only parts (up to $5 \mathrm{k}$ ) of these proteins, with often limited overlap between the various lists. A coordinated multi-laboratory effort will be needed to demarcate the achievable human platelet proteome. In this respect, an update will also be needed of the 2014 reported list of protein copy numbers per platelet [24].

The outcome of quantitative platelet proteomics greatly depends on the method and purity of sample preparation, including the platelet concentration, activation state and all sample processing. Even between recent papers, the described procedures highly deviate. The same holds for platelet 'products' such as the releasate, secretome and extracellular vesicles. We envision that inter-laboratory standardization is needed for better comparison of new study results. As a start, we provide an experience-based protocol (Box 1).

With the platelet proteomic field moving from protein discovery to assessment of protein composition, there is an urgent need for reliable and consistent quantification methods for (core sets of) platelet proteins. In only a few published studies, the judgements on up- or downregulation of proteins were validated by independent means. Hence, in papers comparing subjects or patients, information is missing on the consistency and reproducibility of the found differences. As a solution, we propose duplicate or triplicate workflows on parallel platelet samples, and a consistent use of internal standards.

Analysis of the platelet phosphoproteome has revealed an unexpected wealth of time-dependent regulated protein phosphorylation sites. However, the precision and meaning of the changes in many proteins are unclear, even in stable isotope (iTRAQ, TMT) comparisons. On the other hand, the phosphorylation analysis of platelets from obese subjects and several genotyped patients does provide novel insight into the dysregulation of platelet functions in these disorders.

Several studies report on altered proteomes of stored platelets for transfusion and of released platelet products. The work mostly aims to provide new biomarkers for platelet product quality or the platelet activation state (in vivo). For many proteins with an assumed biomarker role, the physiological functions in platelets are unclear, which asks for a more sophisticated protein function analysis than the conventional pathway analyses (e.g., by Gene Ontology). A recent classification system of all proteins present or expected in platelets may help to achieve this goal [11]. Once a biomarker is confirmed, at a later stage mass spectrometry can be replaced by cheaper, immune-based or flow-cytometry methods in larger (clinical) studies. 
The published studies with patients so far are all limited by low sample sizes, so that common inter-subject variables such as blood cell traits, gender, age and health history are not examined. New high-throughput analysis, using label-free quantification methods in combination with data-independent acquisition, will allow the comparison of multiple platelet samples at the same time, which is conditional for these clinically related questions.

Application of platelet proteomics in the diagnostic laboratory is a challenge due to the expensive and complex requirements in terms of sample preparation and equipment. The additive value of clinical proteomics likely is highest for patients with complex disorders where genetic analysis fails, e.g., in cases of not-understood bleeding, or in metabolic or other systemic diseases. Additionally, otherwise, to understand the action mechanisms of new (antithrombotic) drugs.

In general, we propose that, for the field to move forward, common guidelines should be established that help to improve the inter-lab reproducibility of platelet preparation, proteomic sample processing and complex data analysis. This has also been acknowledged at the 2021 ISTH Congress.

Supplementary Materials: The following are available online at https://www.mdpi.com/article/10 $.3390 /$ ijms22189860/s1.

Author Contributions: Conceptualization, J.H. and P.Z.; resources, A.S., A.G., K.J. and J.W.M.H.; data curation, J.H., P.Z. and F.A.S.; writing - original draft preparation, review and editing, J.H., P.Z., F.A.S., A.G., K.J. and J.W.M.H.; supervision and funding acquisition, A.S., A.G., K.J. and J.W.M.H. All authors have read and agreed to the published version of the manuscript.

Funding: Research support to A.S. and F.S. by the Ministerium für Kultur und Wissenschaft Nordrhein-Westfalen (MKW), by the German Federal Ministry of Education and Research and the Deutsche Forschungsgemeinschaft (TRR240-Z02 and JU 2735/2-1). K.J. is supported by the Ger-man Federal Ministry of Education and Research (BMBF 01EO1503). A.G. is supported by the Spanish Ministry of Science and Innovation (grant No. PID2019-108727RB-I00), co-funded by the European Regional Development Fund (ERDF).

Acknowledgments: J.H. is supported by the European Union's Horizon 2020 research and innovation program under the Marie Sklodowska-Curie grant agreement TAPAS No. 766118, and is enrolled in a joint PhD program of the Universities of Maastricht (The Netherlands) and Santiago de Compostela (Spain). P.Z. is supported by the European Union's Horizon 2020 research and innovation program under the Marie Sklodowska-Curie grant agreement TICARDIO No. 813409. P.Z. is enrolled in a joint PhD program of the Universities of Maastricht (The Netherlands) and Mainz (Germany).

Conflicts of Interest: The authors declare no relevant conflicts of interest.

\section{References}

1. Yau, J.W.; Teoh, H.; Verma, S. Endothelial Cell Control of Thrombosis. BMC Cardiovasc. Disord. 2015, 15, 130. [CrossRef]

2. Van der Meijden, P.E.; Heemskerk, J.W. Platelet Biology and Functions: New Concepts and Clinical Perspectives. Nat. Rev. Cardiol. 2019, 16, 166-179. [CrossRef] [PubMed]

3. Badimon, L.; Vilahur, G. Thrombosis Formation on Atherosclerotic Lesions and Plaque Rupture. J. Int. Med. 2014, $276,618-632$. [CrossRef]

4. Boyanova, D.; Nilla, S.; Birschmann, I.; Dandekar, T.; Dittrich, M. PlateletWeb: A Systems Biologic Analysis of Signaling Networks in Human Platelets. Blood 2012, 119, e22-e34. [CrossRef] [PubMed]

5. Versteeg, H.H.; Heemskerk, J.W.; Levi, M.; Reitsma, P.S. New Fundamentals in Hemostasis. Physiol. Rev. 2013, 93, 327-358. [CrossRef] [PubMed]

6. Weyrich, A.S.; Schwertz, H.; Kraiss, L.W.; Zimmerman, G.A. Protein Synthesis by Platelets: Historical and New Perspectives. J. Thromb. Haemost. 2009, 7, 241-246. [CrossRef]

7. Bray, P.F.; McKenzie, S.E.; Edelstein, L.C.; Nagalla, S.; Delgrosso, K.; Ertel, A.; Kupper, J.; Jing, Y.; Londin, E.; Loher, P.; et al. The Complex Transcriptional Landscape of the Anucleate Human Platelet. BMC Genom. 2013, 14, 1. [CrossRef]

8. Loosse, C.; Swieringa, F.; Heemskerk, J.W.; Sickmann, A.; Lorenz, C. Platelet Proteomics: From Discovery to Diagnosis. Exp. Rev. Proteom. 2018, 15, 467-476. [CrossRef]

9. Mann, M.; Jensen, O.N. Proteomic Analysis of Post-Translational Modifications. Nat. Biotech. 2003, 21, 255-261. [CrossRef]

10. Rosenberger, G.; Koh, C.C.; Guo, T.N.; Rost, H.L.; Kouvonen, P.; Collins, B.; Heusel, M.; Liu, Y.S.; Caron, E.; Vichalkovski, A.; et al. A Repository of Assays to Quantify 10,000 Human Proteins by SWATH-MS. Sci. Data 2014, 1, 140031. [CrossRef] 
11. Huang, J.; Swieringa, F.; Solari, F.A.; Provenzale, I.; Grassi, L.; De Simone, I.; Baaten, C.; Cavill, R.; Sickmann, A.; Frontini, M.; et al. Assessment of a Complete and Classified Platelet Proteome from Genome-Wide Transcripts of Human Platelets and Megakaryo-Cytes Covering Platelet Functions. Sci. Rep. 2021, 11, 12358. [CrossRef]

12. Flores-Villalva, S.; Rogriguez-Hernandez, E.; Rubio-Venegas, Y.; Canto-Alarcon, J.G.; Milian-Suazo, F. What Can Proteomics Tell Us About Tuberculosis? J. Microbiol. Biotechnol. 2015, 25, 1181-1194. [CrossRef]

13. Rijkers, M.; van den Eshof, B.L.; van der Meer, P.F.; van Alphen, F.P.; de Korte, D.; Leebeek, F.W.; Meijer, A.B.; Voorberg, J.; Jansen, A.J. Monitoring Storage Induced Changes in The Platelet Proteome Employing Label Free Quantitative Mass Spectrometry. Sci. Rep. 2017, 7, 11045. [CrossRef] [PubMed]

14. Huang, J.N.; Wang, J.; Li, Q.Q.; Zhang, Y.; Zhang, X.M. Enzyme and Chemical Assisted N-Terminal Blocked Peptides Analysis, Enchant, as A Selective Proteomics Approach Complementary to Conventional Shotgun Approach. J. Proteome Res. 2018, 17, 212-221. [CrossRef] [PubMed]

15. Schmidt, G.J.; Reumiller, C.M.; Ercan, H.; Resch, U.; Butt, E.; Heber, S.; Liutkeviciute, Z.; Basilio, J.; Schmid, J.A.; Assinger, A.; et al. Comparative Proteomics Reveals Unexpected Quantitative Phosphorylation Differences Linked to Platelet Activation State. Sci. Rep. 2019, 9, 19009. [CrossRef] [PubMed]

16. Tabb, D.L.; Vega-Montoto, L.; Rudnick, P.A.; Variyath, A.M.; Ham, A.J.L.; Bunk, D.M.; Kilpatrick, L.E.; Billheimer, D.D.; Blackman, R.K.; Cardasis, H.L.; et al. Repeatability and Reproducibility in Proteomic Identifications by Liquid Chromatography-Tandem Mass Spectrometry. J. Proteome Res. 2010, 9, 761-776. [CrossRef]

17. Cremer, S.E.; Catalfamo, J.L.; Goggs, R.; Seemann, S.E.; Kristensen, A.T.; Brooks, M.B. Proteomic Profiling of The ThrombinActivated Canine Platelet Secretome. PLoS ONE 2019, 14, e0224891. [CrossRef]

18. Cimmino, G.; Tarallo, R.; Nassa, G.; De Filippo, M.R.; Giurato, G.; Ravo, M.; Rizzo, F.; Conte, S.; Pellegrino, G.; Cirillo, P.; et al. Activating Stimuli Induce Platelet Microrna Modulation and Proteome Reorganisation. Thromb. Haemost. 2015, 114, 96-108.

19. Sabrkhany, S.; Kuijpers, M.J.; Knol, J.C.; Damink, S.; Dingemans, A.M.; Verheul, H.M.; Piersma, S.R.; Pham, T.V.; Griffioen, A.W.; Egbrink, M.; et al. Exploration of The Platelet Proteome in Patients with Early-Stage Cancer. J. Proteom. 2018, 177, 65-74. [CrossRef] [PubMed]

20. Izquierdo, I.; Barrachina, M.N.; Hermida-Nogueira, L.; Casas, V.; Moran, L.A.; Lacerenza, S.; Pinto-Llorente, R.; Eble, J.A.; de los Rios, V.; Dominguez, E.; et al. A Comprehensive Tyrosine Phosphoproteomic Analysis Reveals Novel Components of The Platelet Clec-2 Signaling Cascade. Thromb. Haemost. 2020, 120, 262-276. [CrossRef] [PubMed]

21. Bye, A.P.; Unsworth, A.J.; Gibbins, J.M. Platelet Signaling: A Complex Interplay between Inhibitory and Activatory Networks. J. Thromb. Haemost. 2016, 14, 918-930. [CrossRef] [PubMed]

22. Dowal, L.; Yang, W.; Freeman, M.R.; Steen, H.; Flaumenhaft, R. Proteomic Analysis of Palmitoylated Platelet Proteins. Blood 2011, 118, e62-e73. [CrossRef] [PubMed]

23. Lee, H.; Chae, S.; Park, J.; Bae, J.; Go, E.; Kim, S.J.; Kim, H.; Hwang, D.; Lee, S.W.; Lee, S.Y. Comprehensive Proteome Profiling of Platelet Identified A Protein Profile Predictive of Responses to An Antiplatelet Agent Sarpogrelate. Mol. Cell. Proteom. 2016, 15, 3461-3472. [CrossRef] [PubMed]

24. Burkhart, J.M.; Vaudel, M.; Gambaryan, S.; Radau, S.; Walter, U.; Martens, L.; Geiger, J.; Sickmann, A.; Zahedi, R.P. The First Comprehensive and Quantitative Analysis of Human Platelet Protein Composition Allows the Comparative Analysis of Structural and Functional Pathways. Blood 2012, 120, e73-e82. [CrossRef]

25. Burkhart, J.M.; Gambaryan, S.; Watson, S.P.; Jurk, K.; Walter, U.; Sickmann, A.; Heemskerk, J.W.; Zahedi, R.P. What Can Proteomics Tell Us About Platelets? Circ. Res. 2014, 114, 1204-1219. [CrossRef]

26. Klockenbusch, C.; Walsh, G.M.; Brown, L.M.; Hoffman, M.D.; Ignatchenko, V.; Kislinger, T.; Kast, J. Global Proteome Analysis Identifies Active Immunoproteasome Subunits in Human Platelets. Mol. Cell. Proteom. 2014, 13, 3308-3319. [CrossRef]

27. Handtke, S.; Steil, L.; Palankar, R.; Conrad, J.; Cauhan, S.; Kraus, K.; Ferrara, M.; Dhople, V.; Wesche, J.; Völker, U.; et al. Role of Platelet Size Revisited: Function and Protein Composition of Large and Small Platelets. Thromb. Haemost. 2019, 119, 407-420. [CrossRef]

28. Solari, F.A.; Mattheij, N.J.; Burkhart, J.M.; Swieringa, F.; Collins, P.W.; Cosemans, J.; Sickmann, A.; Heemskerk, J.W.; Zahedi, R.P. Combined Quantification of the Global Proteome, Phosphoproteome, and Proteolytic Cleavage to Characterize Altered Platelet Functions in the Human Scott Syndrome. Mol. Cell. Proteom. 2016, 15, 3154-3169. [CrossRef]

29. Swieringa, F.; Solari, F.A.; Pagel, O.; Beck, F.; Huang, J.; Feijge, M.A.H.; Jurk, K.; Körver-Keularts, I.M.L.W.; Mattheij, N.J.A.; Faber, J.; et al. Impaired Iloprost-Induced Platelet Inhibition and Phosphoproteome Changes in Patients with Confirmed Pseudohypoparathyroidism Type Ia, Linked to Genetic Mutations in GNAS. Sci. Rep. 2020, 10, 11389. [CrossRef]

30. Bergemalm, D.; Ramström, S.; Kardeby, C.; Hultenby, K.; Eremo, A.G.; Sihlbom, C.; Bergström, J.; Palmblad, J.; Aström, M. Platelet Proteome and Function in X-Linked Thrombocytopenia with Thalassemia and In Silico Comparisons with Gray Platelet Syndrome. Haematologica 2020. [CrossRef]

31. Sims, M.C.; Mayer, L.; Collins, J.H.; Bariana, T.K.; Megy, K.; Lavenu-Bombled, C.; Seyres, D.; Kollipara, L.; Burden, F.S.; Greene, D.; et al. Novel Manifestations of Immune Dysregulation and Granule Defects in Gray Platelet Syndrome. Blood 2020, 136, $1956-1967$. [CrossRef] [PubMed]

32. Rocheleau, A.D.; Melrose, A.R.; Cunliffe, J.M.; Klimek, J.; Babur, O.; Yunga, S.T.; Ngo, A.T.P.; Pang, J.Q.; David, L.L.; McCarty, O.J.; et al. Identification, Quantification, and System Analysis of Protein N-Epsilon Lysine Methylation in Anucleate Blood Platelets. Proteomics 2019, 19, e1900001. [CrossRef] [PubMed] 
33. Prudova, A.; Serrano, K.; Eckhard, U.; Fortelny, N.; Devine, D.V.; Overall, C.M. TAILS N-Terminomics of Human Platelets Reveals Pervasive Metalloproteinase-Dependent Proteolytic Processing in Storage. Blood 2014, 124, e49-e60. [CrossRef] [PubMed]

34. Schoenichen, C.; Bode, C.; Duerschmied, D. Role of Platelet Serotonin in Innate Immune Cell Recruitment. Front. Biosci. 2019, 24, 514-526.

35. Pang, A.; Cui, Y.; Chen, Y.; Cheng, N.; Delaney, M.K.; Gu, M.; Stojanovic-Terpo, A.; Zhu, C.; Du, X. Shear-Induced Integrin Signaling in Platelet Phosphatidylserine Exposure, Microvesicle Release, and Coagulation. Blood 2018, 132, 533-543. [CrossRef]

36. Zimmerman, G.A.; Weyrich, A.S. Signal-Dependent Protein Synthesis by Activated Platelets: New Pathways to Altered Phenotype and Function. Arterioscler. Thromb. Vasc. Biol. 2008, 28, s17-s24. [CrossRef]

37. Ng, M.S.; Tung, J.P.; Fraser, J.F. Platelet Storage Lesions: What More Do We Know Now? Transfus. Med. Rev. 2018, 32, 144-154. [CrossRef]

38. Thiele, T.; Braune, J.; Dhople, V.; Hammer, E.; Scharf, C.; Greinacher, A.; Volker, U.; Steil, L. Proteomic Profile of Platelets during Reconstitution of Platelet Counts after Apheresis. Proteom. Clin. Appl. 2016, 10, 831-838. [CrossRef] [PubMed]

39. Prudent, M.; Crettaz, D.; Delobel, J.; Tissot, J.D.; Lion, N. Proteomic Analysis of Intercept-Treated Platelets. J. Proteom. 2012, 76, 316-328. [CrossRef]

40. Wang, S.; Jiang, T.; Fan, Y.; Zhao, S. A Proteomic Approach Reveals the Variation in Human Platelet Protein Composition after Storage at Different Temperatures. Platelets 2019, 30, 403-412. [CrossRef] [PubMed]

41. Wood, B.; Padula, M.P.; Marks, D.C.; Johnson, L. Refrigerated Storage of Platelets Initiates Changes in Platelet Surface Marker Expression and Localization of Intracellular Proteins. Transfusion 2016, 56, 2548-2559. [CrossRef]

42. Salunkhe, V.; De Cuyper, I.M.; Papadopoulos, P.; van der Meer, P.F.; Daal, B.D.; Villa-Fajardo, M.; de Korte, D.; van den Berg, T.K.; Gutiérrez, L. A Comprehensive Proteomics Study on Platelet Concentrates: Platelet Proteome, Storage Time and Mirasol Pathogen Reduction Technology. Platelets 2019, 30, 368-379. [CrossRef] [PubMed]

43. Schubert, P.; Culibrk, B.; Karwal, S.; Goodrich, R.P.; Devine, D.V. Protein Translation Occurs in Platelet Concentrates Despite Riboflavin/UV Light Pathogen Inactivation Treatment. Proteom. Clin. Appl. 2016, 10, 839-850. [CrossRef] [PubMed]

44. Sonego, G.; Abonnenc, M.; Crettaz, D.; Lion, N.; Tissot, J.D.; Prudent, M. Irreversible Oxidations of Platelet Proteins after Riboflavin-UVB Pathogen Inactivation. Transfus. Clin. Biol. 2020, 27, 36-42. [CrossRef] [PubMed]

45. Hermida-Nogueira, L.; Barrachina, M.N.; Izquierdo, I.; García-Vence, M.; Lacerenza, S.; Bravo, S.; Castrillo, A.; García, Á. Proteomic Analysis of Extracellular Vesicles Derived From Platelet Concentrates Treated with Mirasol Identifies Biomarkers of Platelet Storage Lesion. J. Proteom. 2020, 210, 103529. [CrossRef] [PubMed]

46. Aloui, C.; Barlier, C.; Claverol, S.; Fagan, J.; Awounou, D.; Tavernier, E.; Guyotat, D.; Hamzeh-Cognasse, H.; Cognasse, F.; Garraud, O.; et al. Differential Protein Expression of Blood Platelet Components Associated with Adverse Transfusion Reactions. J. Proteom. 2019, 194, 25-36. [CrossRef]

47. Aloui, C.; Barlier, C.; Awounou, D.; Thiam, S.; Fagan, J.; Claverol, S.; Tavernier, E.; Mounier, C.; Hamzeh-Cognasse, H.; Cognasse, F.; et al. Dysregulated Pathways and Differentially Expressed Proteins Associated with Adverse Transfusion Reactions in Different Types of Platelet Components. J. Proteom. 2020, 218, 103717. [CrossRef]

48. Nieswandt, B.; Watson, S.P. Platelet-Collagen Interaction: Is GPVI the Central Receptor? Blood 2003, 102, 449-461. [CrossRef]

49. Perrella, G.; Huang, J.; Provenzale, I.; Swieringa, F.; Heubel-Moenen, F.C.; Farndale, R.W.; Roest, M.; van der Meijden, P.E.; Thomas, M.; Ariëns, R.A.; et al. Non-Redundant Roles of Platelet Glycoprotein VI and Integrin aIIbb3 in Fibrin-Mediated Microthrombus Formation. Arterioscler. Thromb. Vasc. Biol. 2021, 41, e97-e111. [CrossRef]

50. Nagy, M.; van Geffen, J.P.; Stegner, D.; Adams, D.; Braun, A.; de Witt, S.M.; Elvers, M.; Kuijpers, M.J.; Kunzelmann, K.; Oury, C.; et al. Comparative Analysis of Microfluidics Thrombus Formation in Multiple Genetically Modified Mice: Link to Thrombosis and Hemostasis. Front. Cardiovasc. Med. 2019, 6, 99. [CrossRef]

51. Baaten, C.C.; Meacham, S.; de Witt, S.M.; Feijge, M.A.; Adams, D.J.; Akkerman, J.W.; Cosemans, J.M.; Grassi, L.; Jupe, S.; Kostadima, M.; et al. A Synthesis Approach of Mouse Studies to Identify Genes and Proteins in Arterial Thrombosis and Bleeding. Blood 2018, 132, e35-e46. [CrossRef]

52. Konstantinides, S.; Ware, J.; Marchese, P.; Almus-Jacobs, F.; Loskutoff, D.J.; Ruggeri, Z.M. Distinct Antithrombotic Consequences of Platelet Glycoprotein Iba and VI Deficiency in a Mouse Model of Arterial Thrombosis. J. Thromb. Haemost. 2006, 4, $2014-2021$. [CrossRef]

53. Watson, S.P.; Herbert, J.M.; Pollitt, A.Y. GPVI and CLEC-2 in Hemostasis and Vascular Integrity. J. Thromb. Haemost. 2010, 8, 1457-1467. [CrossRef]

54. Hughes, C.E.; Finney, B.A.; Koentgen, F.; Lowe, K.L.; Watson, S.P. The N-Terminal SH2 Domain of Syk Is Required for (hem)ITAM, but Not Integrin, Signaling in Mouse Platelets. Blood 2015, 125, 144-154. [CrossRef] [PubMed]

55. Matus, V.; Valenzuela, G.; Saez, C.G.; Hidalgo, P.; Lagos, M.; Aranda, E.; Panes, O.; Pereira, J.; Pillois, X.; Nurden, A.T.; et al. An Adenine Insertion in Exon 6 of Human GP6 Generates a Truncated Protein Associated with a Bleeding Disorder in Four Chilean Families. J. Thromb. Haemost. 2013, 11, 1751-1759. [CrossRef] [PubMed]

56. Jandrot-Perrus, M.; Hermans, C.; Mezzano, D. Platelet Glycoprotein VI Genetic Quantitative and Qualitative Defects. Platelets 2019, 30, 708-713. [CrossRef] [PubMed]

57. Garcia, A. Proteome Analysis of Signaling Cascades in Human Platelets. Blood Cells Mol. Dis. 2006, 36, 152-156. [CrossRef] 
58. Schulz, C.; Leuschen, N.V.; Frohlich, T.; Lorenz, M.; Pfeiler, S.; Gleissner, C.A.; Kremmer, E.; Kessler, M.; Khandoga, A.G.; Engelmann, B.; et al. Identification of Novel Downstream Targets of Platelet Glycoprotein VI Activation by Differential Proteome Analysis: Implications for Thrombus Formation. Blood 2010, 115, 4102-4110. [CrossRef] [PubMed]

59. Babur, O.; Melrose, A.R.; Cunliffe, J.M.; Klimek, J.; Pang, J.; Sepp, A.I.; Zilberman-Rudenko, J.; Tassi Yunga, S.; Zheng, T.; Parra-Izquierdo, I.; et al. Phosphoproteomic Quantitation and Causal Analysis Reveal Pathways in GPVI/ITAM-Mediated Platelet Activation Programs. Blood 2020, 136, 2346-2358. [CrossRef]

60. Velez, P.; Ocaranza-Sanchez, R.; Lopez-Otero, D.; Grigorian-Shamagian, L.; Rosa, I.; Guitian, E.; Garcia-Acuna, J.M.; GonzalezJuanatey, J.R.; Garcia, A. Alteration of Platelet GPVI Signaling in ST-Elevation Myocardial Infarction Patients Demonstrated by a Combination of Pro-Teomic, Biochemical, and Functional Approaches. Sci. Rep. 2016, 6, 39603. [CrossRef]

61. Barrachina, M.N.; Hermida-Nogueira, L.; Moran, L.A.; Casas, V.; Hicks, S.M.; Sueiro, A.M.; Di, Y.; Andrews, R.K.; Watson, S.P.; Gardiner, E.E.; et al. Phosphoproteomic Analysis of Platelets in Severe Obesity Uncovers Platelet Reactivity and Signaling Pathways Alterations. Arterioscler. Thromb. Vasc. Biol. 2021, 41, 478-490. [PubMed]

62. Aslan, J.E.; Rigg, R.A.; Nowak, M.S.; Loren, C.P.; Baker-Groberg, S.M.; Pang, J.; David, L.L.; McCarty, O.J. Lysine Acetyltransfer Supports Platelet Function. J. Thromb. Haemost. 2015, 13, 1908-1917. [CrossRef]

63. Shah, P.; Yang, W.; Sun, S.; Pasay, J.; Faraday, N.; Zhang, H. Platelet Glycoproteins Associated with Aspirin-Treatment upon Platelet Activation. Proteomics 2017, 17, 1600199. [CrossRef] [PubMed]

64. Toonstra, C.; Hu, Y.; Zhang, H. Deciphering the Roles of N-Glycans on Collagen-Platelet Interactions. J. Proteome Res. 2019, 18, 2467-2477. [CrossRef]

65. Unsworth, A.J.; Bombik, I.; Pinto-Fernandez, A.; McGouran, J.F.; Konietzny, R.; Zahedi, R.P.; Watson, S.P.; Kessler, B.M.; Pears, C.J. Human Platelet Protein Ubiquitylation and Changes Following GPVI Activation. Thromb. Haemost. 2019, 119, 104-116. [CrossRef] [PubMed]

66. Durrant, T.N.; Hutchinson, J.L.; Heesom, K.J.; Anderson, K.E.; Stephens, L.R.; Hawkins, P.T.; Marshall, A.J.; Moore, S.F.; Hers, I. In-Depth PtdIns $(3,4,5) \mathrm{P}_{3}$ Signalosome Analysis Identifies DAPP1 as a Negative Regulator of GPVI-Driven Platelet Function. Blood Adv. 2017, 1, 918-932. [CrossRef]

67. Izquierdo, I.; Barrachina, M.N.; Hermida-Nogueira, L.; Casas, V.; Eble, J.E.; Carrascal, M.; Abian, J.; García, A. Platelet Membrane Lipid Rafts Protein Composition Varies Following GPVI and CLEC-2 Receptors Activation. J. Proteom. 2019, 195, 88-97. [CrossRef]

68. Bleijerveld, O.B.; van Holten, T.C.; Preisinger, C.; van der Smagt, J.J.; Farndale, R.W.; Kleefstra, T.; Willemsen, M.H.; Urbanus, R.T.; de Groot, P.G.; Heck, A.J.; et al. Targeted Phosphotyrosine Profiling of Glycoprotein VI Signaling Implicates Oligophrenin-1 in Platelet Filopodia Formation. Arterioscler. Thromb. Vasc. Biol. 2013, 33, 1538-1543. [CrossRef]

69. De Witt, S.; Verdoold, R.; Cosemans, J.M.E.M.; Heemskerk, J.W.M. Insights into Platelet-Based Control of Coagulation. Thromb. Res. 2014, 133, 139-148. [CrossRef]

70. Heemskerk, J.W.; Cosemans, J.M.; van der Meijden, P.E. Platelets and Coagulation. In Platelets in Thrombotic and Non-Thrombotic Disorders; Gresele, P., Kleiman, N.S., Lopez, J.A., Page, C.P., Eds.; Springer: Cham, Switzerland, 2017; pp. 447-462. ISBN 978-3-319-47460-1.

71. Agbani, E.O.; van den Bosch, M.T.; Brown, E.; Williams, C.M.; Mattheij, N.J.; Cosemans, J.M.; Collins, P.W.; Heemskerk, J.W.; Hers, I.; Poole, A.W. Coordinated Membrane Ballooning and Procoagulant Spreading in Human Platelets. Circulation 2015, 132, 1414-1424. [CrossRef]

72. Rayes, J.; Watson, S.P.; Nieswandt, B. Functional Significance of the Platelet Immune Receptors GPVI and CLEC-2. J. Clin. Investig. 2019, 129, 12-23. [CrossRef]

73. Suzuki-Inoue, K.; Fuller, G.L.; Garcia, A.; Eble, J.A.; Pohlmann, S.; Inoue, O.; Gartner, T.K.; Hughan, S.C.; Pearce, A.C.; Laing, G.D.; et al. A Novel Syk-Dependent Mechanism of Platelet Activation by the C-Type Lectin Receptor CLEC-2. Blood 2006, 107, 542-549. [CrossRef]

74. Manne, B.K.; Badolia, R.; Dangelmaier, C.; Eble, J.A.; Ellmeier, W.; Kahn, M.; Kunapuli, S.P. Distinct Pathways Regulate Syk Protein Activation Downstream of Immune Tyrosine Activation Motif (ITAM) and hemITAM Receptors in Platelets. J. Biol. Chem. 2015, 290, 11557-11568. [CrossRef]

75. Parguina, A.F.; Alonso, J.; Rosa, I.; Velez, P.; Gonzalez-Lopez, M.J.; Guitian, E.; Ebble, J.A.; Loza, M.I.; Garcia, A. A Detailed Proteomic Analysis of Rhodocytin-Activated Platelets Reveals Novel Clues on the CLEC-2 Signalosome: Implications for CLEC-2 Signaling Regulation. Blood 2012, 120, e117-e126. [CrossRef]

76. Coughlin, S.R. Thrombin Signalling and Protease-Activated Receptors. Nature 2000, 407, 258-264. [CrossRef]

77. Wu, J.; Heemskerk, J.W.; Baaten, C.C. Platelet Membrane Receptor Proteolysis: Implications for Platelet Function. Front. Cardiovasc. Med. 2020, 7, 608391. [CrossRef]

78. Estevez, B.; Kim, K.; Delaney, M.K.; Stojanovic-Terpo, A.; Shen, B.; Ruan, C.G.; Cho, J.Y.; Ruggeri, Z.M.; Du, X.P. SignalingMediated Cooperativity Between Glycoprotein Ib-IX and Protease-Activated Receptors in Thrombin-Induced Platelet Activation. Blood 2016, 127, 626-636. [CrossRef]

79. Mammadova-Bach, E.; Nagy, M.; Heemskerk, J.W.; Nieswandt, N.; Braun, A. Store-Operated Calcium Entry in Blood Cells in Thrombo-Inflammation. Cell Calcium 2019, 77, 39-48. [CrossRef]

80. Fernandez, D.I.; Kuijpers, M.J.; Heemskerk, J.W. Platelet Calcium Signalling by G-Protein Coupled and ITAM-Linked Receptors Regulating Anoctamin-6 and Procoagulant Activity. Platelets 2020, 32, 863-871. [CrossRef] 
81. Kim, S.; Foster, C.; Lecchi, A.; Quinton, T.M.; Prosser, D.M.; Jin, J.G.; Cattaneo, M.; Kunapuli, S.P. Protease-Activated Receptors 1 and 4 Do Not Stimulate Gi Signaling Pathways in the Absence of Secreted ADP and Cause Human Platelet Aggregation Independently of Gi Signaling. Blood 2002, 99, 3629-3636. [CrossRef]

82. Moers, A.; Nieswandt, B.; Massberg, S.; Wettschureck, N.; Gruner, S.; Konrad, I.; Schulte, V.; Aktas, B.; Gratacap, M.P.; Simon, M.I.; et al. G13 Is an Essential Mediator of Platelet Activation in Hemostasis and Thrombosis. Nat. Med. 2003, 9, 1418-1422. [CrossRef]

83. Pagel, O.; Walter, E.; Jurk, K.; Zahedi, R.P. Taking the Stock of Granule Cargo: Platelet Releasate Proteomics. Platelets 2017, 28, 119-128. [CrossRef]

84. Velez, P.; Izquierdo, I.; Rosa, I.; Garcia, A. A 2D-DIGE-Based Proteomic Analysis Reveals Differences in the Platelet Releasate Composition When Comparing Thrombin and Collagen Stimulations. Sci. Rep. 2015, 5, 8198. [CrossRef]

85. Szklanna, P.B.; Parsons, M.E.; Wynne, K.; O’Connor, H.; Egan, K.; Allen, S.; Ní Áinle, F.; Maguire, P.B. The Platelet Releasate Is Altered in Human Pregnancy. Proteom. Clin. Appl. 2019, 13, e1800162. [CrossRef]

86. Parsons, M.E.; Szklanna, P.B.; Guerrero, J.A.; Wynne, K.; Dervin, F.; O'Connell, K.; Allen, S.; Egan, K.; Bennett, C.; McGuigan, C.; et al. Platelet Releasate Proteome Profiling Reveals a Core Set of Proteins with Low Variance between Healthy Adults. Proteomics 2018, 18, e1800219. [CrossRef]

87. Milioli, M.; Ibanez-Vea, M.; Sidoli, S.; Palmisano, G.; Careri, M.; Larsen, M.R. Quantitative Proteomics Analysis of Platelet-Derived Microparticles Reveals Distinct Protein Signatures When Stimulated by Different Physiological Agonists. J. Proteom. 2015, 121, 55-66. [CrossRef]

88. Grande, R.; Dovizio, M.; Marcone, S.; Szklanna, P.B.; Bruno, A.; Ebhardt, H.A.; Cassidy, H.; Ainle, F.N.; Caprodossi, A.; Lanuti, P.; et al. Platelet-Derived Microparticles from Obese Individuals: Characterization of Number, Size, Proteomics, and Crosstalk with Cancer and Endothelial Cells. Front. Pharmacol. 2019, 10, 7. [CrossRef]

89. Garcia, A.; Prabhakar, S.; Hughan, S.; Anderson, T.W.; Brock, C.J.; Pearce, A.C.; Dwek, R.A.; Watson, S.P.; Hebestreit, H.F.; Zitzmann, N. Differential Proteome Analysis of TRAP-Activated Platelets: Involvement of DOK-2 and Phosphorylation of RGS Proteins. Blood 2004, 103, 2088-2095. [CrossRef]

90. Tsai, H.J.; Chien, K.Y.; Liao, H.R.; Shih, M.S.; Lin, Y.C.; Chang, Y.W.; Cheng, J.C.; Tseng, C.P. Functional Links between Disabled-2 Ser723 Phosphorylation and Thrombin Signaling in Human Platelets. J. Thromb. Haemost. 2017, 15, 2029-2044. [CrossRef] [PubMed]

91. Zufferey, A.; Ibberson, M.; Reny, J.L.; Nolli, S.; Schvartz, D.; Docquier, M.; Xenarios, I.; Sanchez, J.C.; Fontana, P. New Molecular Insights into Modulation of Platelet Reactivity in Aspirin-Treated Patients Using a Network-Based Approach. Hum. Genet. 2016, 135, 403-414. [CrossRef] [PubMed]

92. Fontana, P.; Zufferey, A.; Daali, Y.; Reny, J.L. Antiplatelet Therapy: Targeting the TxA2 Pathway. J. Cardiovasc. Translat. Res. 2014, 7, 29-38. [CrossRef]

93. Offermanns, S. Activation of Platelet Function through G Protein-Coupled Receptors. Circ. Res. 2006, 99, 1293-1304. [CrossRef]

94. Stokhuijzen, E.; Koornneef, J.M.; Nota, B.; van den Eshof, B.L.; van Alphen, F.P.; van den Biggelaar, M.; van der Zwaan, C.; Kuijk, C.; Mertens, K.; Fijnvandraat, K.; et al. Differences between Platelets Derived from Neonatal Cord Blood and Adult Peripheral Blood Assessed by Mass Spectrometry. J. Proteome Res. 2017, 16, 3567-3575. [CrossRef] [PubMed]

95. Jakubowski, M.; Debski, J.; Szahidewicz-Krupska, E.; Turek-Jakubowska, A.; Gawrys, J.; Gawrys, K.; Skomro, R.; Derkacz, A.; Doroszko, A. Platelet Carbonic Anhydrase II, a Forgotten Enzyme, May Be Responsible for Aspirin Resistance. Oxid. Med. Cell Longev. 2017, 2017, 3132063. [CrossRef] [PubMed]

96. Finamore, F.; Reny, J.L.; Malacarne, S.; Fontana, P.; Sanchez, J.C. Shotgun Proteomics Data on the Impact of Hyperglycaemia on Platelet Protein Acetylation by Aspirin. Data Brief 2018, 21, 2475-2481. [CrossRef]

97. Finamore, F.; Reny, J.L.; Malacarne, S.; Fontana, P.; Sanchez, J.C. A High Glucose Level Is Associated with Decreased AspirinMediated Acetylation of Platelet Cyclooxygenase (COX)-1 at Serine 529: A Pilot Study. J. Proteom. 2019, 192, 258-266. [CrossRef]

98. Gachet, C.; Hechler, B.; Leon, C.; Vial, C.; Leray, C.; Ohlmann, P.; Cazenave, J.P. Activation of ADP Receptors and Platelet Function. Thromb. Haemost. 1997, 78, 271-275. [CrossRef]

99. Monroe, D.M.; Hoffman, M. What Does It Take to Make the Perfect Clot? Arterioscler. Thromb. Vasc. Biol. 2006, 26, 41-48. [CrossRef] [PubMed]

100. Rukoyatkina, N.; Walter, U.; Friebe, A.; Gambaryan, S. Differentiation of cGMP-Dependent and-Independent Nitric Oxide Effects on Platelet Apoptosis and Reactive Oxygen Species Production Using Platelets Lacking Soluble Guanylyl Cyclase. Thromb. Haemost. 2011, 106, 922-933. [CrossRef]

101. Beck, F.; Geiger, J.; Gambaryan, S.; Veit, J.; Vaudel, M.; Nollau, P.; Kohlbacher, O.; Martens, L.; Walter, U.; Sickmann, A.; et al. Time-Resolved Characterization of cAMP/PKA-Dependent Signaling Reveals That Platelet Inhibition Is a Concerted Process Involving Multiple Signaling Pathways. Blood 2014, 123, e1-e10. [CrossRef]

102. Beck, F.; Geiger, J.; Gambaryan, S.; Solari, F.A.; Dell'Aica, M.; Loroch, S.; Mattheij, N.J.; Mindukshev, I.; Potz, O.; Jurk, K.; et al. Temporal Quantitative Phosphoproteomics of ADP Stimulation Reveals Novel Central Nodes in Platelet Activation and Inhibition. Blood 2017, 129, e1-e12. [CrossRef]

103. Radomski, M.W.; Palmer, R.M.; Moncada, S. Comparative Pharmacology of Endothelium-Derived Relaxing Factor, Nitric Oxide and Prostacyclin in Platelets. Br. J. Pharmacol. 1987, 92, 181-187. [CrossRef] 
104. Makhoul, S.; Walter, E.; Pagel, O.; Walter, U.; Sickmann, A.; Gambaryan, S.; Smolenski, A.; Zahedi, R.P.; Jurk, K. Effects of the NO/Soluble Guanylate Cyclase/cGMP System on the Functions of Human Platelets. Nitric Oxide 2018, 76, 71-80. [CrossRef] [PubMed]

105. Dangel, O.; Mergia, E.; Karlisch, K.; Groneberg, D.; Koesling, D.; Friebe, A. Nitric Oxide-Sensitive Guanylyl Cyclase Is the Only Nitric Oxide Receptor Mediating Platelet Inhibition. J. Thromb. Haemost. 2010, 8, 1343-1352. [CrossRef]

106. Kumm, E.J.; Pagel, O.; Gambaryan, S.; Walter, U.; Zahedi, R.P.; Smolenski, A.; Jurk, K. The Cell Cycle Checkpoint System MAST(L)-ENSA/ARPP19-PP2A Is Targeted by cAMP/PKA and cGMP/PKG in Anucleate Human Platelets. Cells 2020, 9, 472. [CrossRef]

107. Makhoul, S.; Dorschel, S.; Gambaryan, S.; Walter, U.; Jurk, K. Feedback Regulation of Syk by Protein Kinase C in Human Platelets. Int. J. Mol. Sci. 2019, 21, 176. [CrossRef] [PubMed]

108. Loroch, S.; Trabold, K.; Gambaryan, S.; Reiss, C.; Schwierczek, K.; Fleming, I.; Sickmann, A.; Behnisch, W.; Zieger, B.; Zahedi, R.P.; et al. Alterations of the Platelet Proteome in Type I Glanzmann Thrombasthenia Caused by Different Homozygous deIG Frameshift Mutations in ITGA2B. Thromb. Haemost. 2017, 117, 556-569. [CrossRef]

109. Van Kruchten, R.; Mattheij, N.J.; Saunders, C.; Feijge, M.A.; Swieringa, F.; Wolfs, J.L.; Collins, P.W.; Heemskerk, J.W.; Bevers, E.M. Both TMEM16F-Dependent and TMEM16F-Independent Pathways Contribute to Phosphatidylserine Exposure in Platelet Apoptosis and Platelet Activation. Blood 2013, 121, 1850-1857. [CrossRef]

110. Van Bergen, M.G.; Marneth, A.E.; Hoogendijk, A.J.; van Alphen, F.P.; van den Akker, E.; Laros-Van Gorkom, B.A.; Hoeks, M.; Simons, A.; de Munnik, S.A.; Janssen, J.J.; et al. Specific Proteome Changes in Platelets from Individuals with GATA1-, GFI1B-, and RUNX1-Linked Bleeding Disorders. Blood 2021, 138, 86-90. [CrossRef]

111. Bijak, M.; Olejnik, A.; Rokita, B.; Morel, A.; Dziedzic, A.; Miller, E.; Saluk-Bijak, J. Increased Level of Fibrinogen Chains in the Proteome of Blood Platelets in Secondary Progressive Multiple Sclerosis Patients. J. Cell Mol. Med. 2019, 23, 3476-3482. [CrossRef] [PubMed]

112. Trugilho, M.R.; Hottz, E.D.; Brunoro, G.V.; Teixeira-Ferreira, A.; Carvalho, P.C.; Salazar, G.A.; Zimmerman, G.A.; Bozza, F.A.; Bozza, P.T.; Perales, J. Platelet Proteome Reveals Novel Pathways of Platelet Activation and Platelet-Mediated Immunoregulation in Dengue. PLoS Pathog. 2017, 13, e1006385. [CrossRef]

113. Yu, H.; Liu, Y.; He, B.; He, T.; Chen, C.; He, J.; Yang, X.; Wang, J.Z. Platelet Biomarkers for a Descending Cognitive Function: A Proteomic Approach. Aging Cell 2021, 20, e13358. [CrossRef]

114. Parguina, A.F.; Grigorian-Shamajian, L.; Agra, R.M.; Teijeira-Fernandez, E.; Rosa, I.; Alonso, J.; Vinuela-Roldan, J.E.; Seoane, A.; Gonzalez-Juanatey, J.R.; Garcia, A. Proteins Involved in Platelet Signaling Are Differentially Regulated in Acute Coronary Syndrome: A Proteomic Study. PLoS ONE 2010, 5, e13404.

115. Lopez-Farré, A.J.; Zamorano-Leon, J.J.; Azcona, L.; Modrego, J.; Mateos-Caceres, P.J.; Gonzalez-Armengol, J.; Villarroel, P.; Moreno-Herrero, R.; Rodríguez-Sierra, P.; Segura, A.; et al. Proteomic Changes Related to Bewildered Circulating Platelets in the Acute Coronary Syndrome. Proteomics 2011, 11, 3335-3348. [CrossRef]

116. Velez, P.; Ocaranza-Sanchez, R.; Lopez-Otero, D.; Grigorian-Shamagian, L.; Rosa, I.; Belen Bravo, S.; Gonzalez-Juanatey, J.R.; Garcia, A. 2D-DIGE-Based Proteomic Analysis of Intracoronary vs. Peripheral Arterial Blood Platelets from Acute Myocardial Infarction Patients: Upregulation of Platelet Activation Biomarkers at the Culprit Site. Proteom. Clin. Appl. 2016, 10, 851-858. [CrossRef]

117. Maguire, P.B.; Parsons, M.E.; Szklanna, P.B.; Zdanyte, M.; Münzer, P.; Chatterjee, M.; Wynne, K.; Rath, D.; Comer, S.P.; Hayden, M.; et al. Comparative Platelet Releasate Proteomic Profiling of Acute Coronary Syndrome vs. Stable Coronary Artery Disease. Front. Cardiovasc. Med. 2020, 7, 101. [CrossRef] [PubMed]

118. Hell, L.; Lurger, K.; Mauracher, L.M.; Grilz, E.; Reumiller, C.M.; Schmidt, G.J.; Ercan, H.; Koder, S.; Assinger, A.; Basilio, J.; et al Altered Platelet Proteome in Lupus Anticoagulant-Positive Patients-Protein Disulfide Isomerase and NETosis as New Players in LA-Related Thrombosis. Exp. Mol. Med. 2020, 52, 66-78. [CrossRef]

119. Van Geffen, J.P.; Swieringa, F.; van Kuijk, K.; Tullemans, B.M.; Solari, F.A.; Peng, B.; Clemetson, K.J.; Farndale, R.W.; Dubois, L.J.; Sickmann, A.; et al. Mild Hyperlipidemia in Mice Aggravates Platelet Responsiveness in Thrombus Formation and Exploration of Platelet Proteome and Lipidome. Sci. Rep. 2020, 10, 21407. [CrossRef]

120. Malchow, S.; Loosse, C.; Sickmann, A.; Lorenz, C. Quantification of Cardiovascular Disease Biomarkers in Human Platelets by Targeted Mass Spectrometry. Proteomes 2017, 5, 31. [CrossRef] [PubMed]

121. Zougman, A.; Selby, P.J.; Banks, R.E. Suspension Trapping (STrap) Sample Preparation Method for Bottom-Up Proteomics Analysis. Proteomics 2014, 14, 1006. [CrossRef]

122. Ludwig, K.R.; Schroll, M.M.; Hummon, A.B. Comparison of Insolution, FASP, and S-Trap Based Digestion Methods for Bottom-Up Proteomic Studies. J. Proteome Res. 2018, 17, 2480-2490. [CrossRef]

123. Zhu, Y.; Piehowski, P.D.; Zhao, R.; Chen, J.; Shen, Y.; Moore, R.J.; Shukla, A.K.; Petyuk, V.A.; Campbell-Thompson, M.; Mathews, C.E.; et al. Nanodroplet Processing Platform for Deep and Quantitative Proteome Profiling of 10-100 Mammalian Cells. Nat. Commun. 2018, 9, 882. [CrossRef] [PubMed]

124. Ruprecht, B.; Koch, H.; Medard, G.; Mundt, M.; Kuster, B.; Lemeer, S. Comprehensive and Reproducible Phosphopeptide Enrichment Using Iron Immobilized Metal Ion Affinity Chromatography (Fe-IMAC) Columns. Mol. Cell. Proteom. 2015, 14, 205-215. [CrossRef] [PubMed] 
125. Chen, C.; Hou, J.; Tanner, J.J.; Cheng, J. Bioinformatics Methods for Mass Spectrometry-Based Proteomics Data Analysis. Int. J. Mol. Sci. 2020, 21, 2873. [CrossRef] [PubMed]

126. Solari, F.A.; Dell'Aica, M.; Sickmann, A.; Zahedi, R.P. Why Phosphoproteomics Is Still a Challenge. Mol. Biosyst. 2015, 11, 1487-1493. [CrossRef] 